OECDpublishing

\title{
FINANCING SOCIAL PROTECTION IN NAMIBIA
}

\section{OECD DEVELOPMENT POLICY PAPERS}

April $2019 \mathbf{n}^{\circ} \mathbf{1 9}$ 


\section{OECD Development Policy Papers}

April 2019 - No. 19

\section{Financing Social Protection in Namibia}

By Klaus Schade, Justina La and Alexander Pick 
This work is published under the responsibility of the Secretary-General of the OECD. The opinions expressed and arguments employed herein do not necessarily reflect those of the OECD, its Development Centre or of their member countries.

This document, and any map included herein, are without prejudice to the status of or sovereignty over any territory, to the delimitation of international frontiers and boundaries and to the name of any territory, city or area.

This document was authorised for publication by Mario Pezzini, Director of the Development Centre and Special Advisor to the OECD Secretary-General on Development.

Keywords: Namibia, social protection, financing, inclusive growth, pensions, health

JEL classification: I38, H53, H55, H61.

Photo credit: Cover by the OECD Development Centre.

(C) OECD 2019 


\section{Abstract}

Namibia is an upper middle-income country with one of the most comprehensive social protection systems in Africa. It provides cash transfers and complementary social assistance to a range of vulnerable groups including children, the elderly and people with disabilities, at a cost equivalent to 4.5\% of GDP in 2016/17. Public-sector workers are well covered by social insurance, although there are gaps in provision for the private sector. Social protection, in particular cash transfers, has proven highly effective at reducing poverty and inequality and mitigating the impact of high unemployment, although these remain persistent challenges. For Namibia to achieve its development objectives, social protection will need to play an even greater role in the future, but scaling up social protection in the current context of low economic growth and fiscal consolidation will be challenging. This paper charts the evolution of social protection provision and expenditure, locates social protection within the context of Namibia's broader fiscal framework and proposes options for enhancing its impact without increasing public spending. 



\title{
Preface
}

Namibia has one of the most comprehensive social protection systems in Africa. It includes public and private arrangements that cover individuals at a range of income levels against a variety of risks. Equivalent to $13 \%$ of gross domestic product, annual spending on social protection matches the breadth and depth of provision. Still, social protection is currently not making sufficient progress in eliminating persistent and deeprooted poverty (especially amongst children), inequality and unemployment.

The Government of the Republic of Namibia has scaled up social protection significantly over the past two decades to address these challenges. However, the fiscal space available to continue to do so is limited because of low economic growth since 2016, higher debt levels, weak revenues and a sizeable public sector wage bill that have entailed a period of fiscal consolidation.

This paper analyses the evolution of social protection in Namibia from a financial perspective. It examines how investment in social protection - both in absolute terms and as a proportion of total government spending - has grown since the early 2000s. It adopts a systems-based approach to analysing spending on social assistance, social insurance and labour market policies to understand the sustainability of individual programmes and the system as a whole as well as to pinpoint where gaps might exist.

Particular attention is paid to the overarching challenge of increasing the impact of social protection in a fiscally-constrained environment through reprioritisation, streamlining and better information systems. In this way, we believe this paper will be of interest to Namibia and to other countries with relatively well-developed social protection systems that intend to improve their effectiveness and value-for-money.

This paper is a collaboration between the OECD Development Centre and the Economic Association of Namibia as part of the European Union Social Protection Systems Programme. It is intended to inform Namibia's first-ever national social protection policy, which the Namibian government is currently developing. This paper would not have been possible without the support of a number of stakeholders, including Namibia's Ministry of Poverty Eradication and Social Welfare.

\author{
Mario Pezzini \\ Director of the OECD Development Centre \\ and Special Advisor to the OECD Secretary-General \\ on Development
}




\section{Acknowledgements}

This paper was written by Klaus Schade (Economic Association of Namibia), Justina La and Alexander Pick (OECD Development Centre) as part of the European Union Social Protection Systems Programme (EU-SPS). It was written under the supervision of Alexandre Kolev, Head of the Social Cohesion Unit of the OECD Development Centre, with the guidance of Mario Pezzini, Director of the OECD Development Centre and Special Advisor to the OECD Secretary-General on Development. The paper was initiated by Riku Elovainio and produced by Elizabeth Nash of the OECD Development Centre.

The paper was reviewed by (and received valuable input from) Willem Adema (Senior Economist in the OECD Employment, Labour and Social Affairs Directorate) and Arthur Minsat (Head of the Africa Unit in the OECD Development Centre). It also benefited from comments from Esther Lusepani, Permanent Secretary of Namibia's Ministry of Poverty Eradication and Social Welfare.

The European Union Social Protection Systems Programme is co-financed by the European Union, the OECD and the Government of Finland.

This study has been produced with the assistance of the European Union and Finland. The contents of this study are the sole responsibility of the OECD and can in no way be taken to reflect the views of the European Union or the Government of Finland. 


\section{Table of contents}

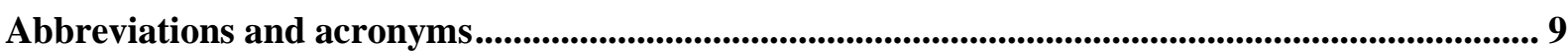

Executive summary ..................................................................................................................................................... 10

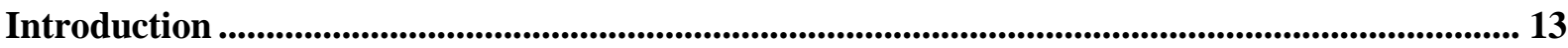

1. Mapping Namibia's social protection system ..................................................................................... 15

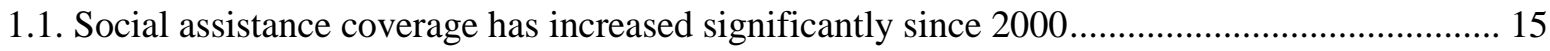

1.2. Public sector workers receive comprehensive social insurance coverage .................................. 20

1.3. A range of labour market activation schemes are in place....................................................... 21

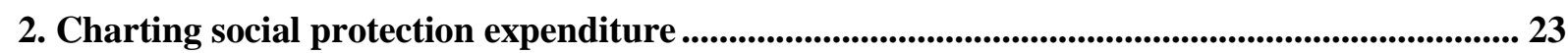

2.1. Social assistance accounts for a growing proportion of public spending ................................... 26

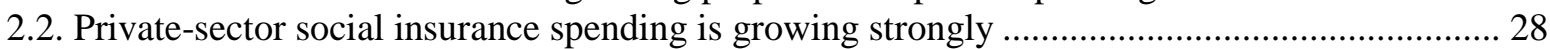

2.3. Labour market activation and broad social protection programmes ....................................... 30

3. Social protection in Namibia's fiscal framework....................................................................................... 33

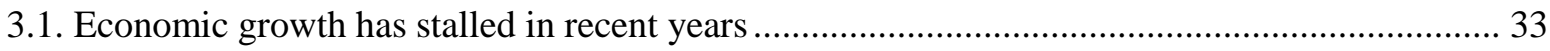

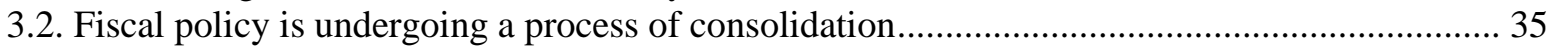

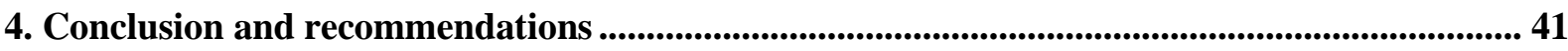

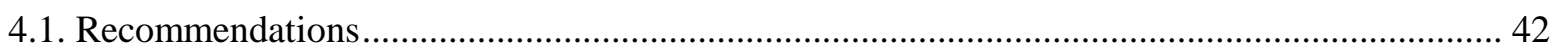

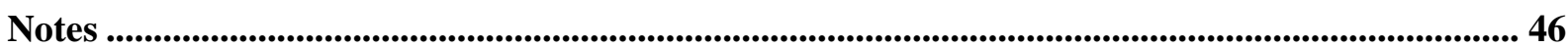

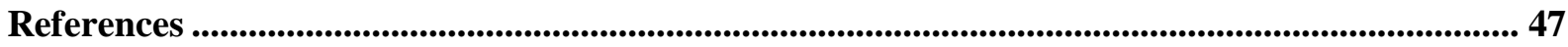

Annex A. Classification of social protection programmes ........................................................................ 50

Annex B. Public expenditure on social protection in Namibia (2000-17) ........................................... 52

\section{Tables}

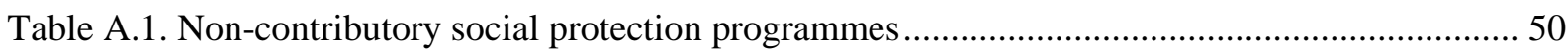

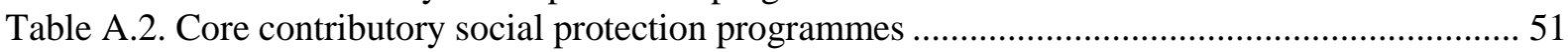

Table B.1. Total expenditure on non-contributory programmes, in NAD million............................... 52

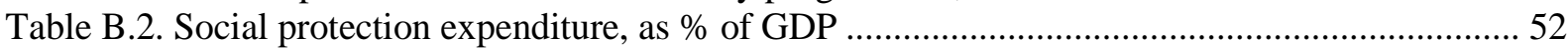

Table B.3. Social protection expenditure, as $\%$ of total public expenditure …................................... 52

Table B.4. Core non-contributory and contributor social protection expenditure, per capita, in NAD 53 


\section{Figures}

Figure 1.1. Social assistance benefits are largest for veterans, smallest for children

Figure 1.2. Old age and disability grants have increased in real terms but child grants have declined 18

Figure 1.3. Social assistance programmes are expanding coverage of children and seniors

Figure 2.1. Social assistance spending has increased over the last decade ......................................... 23

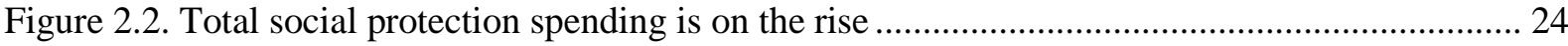

Figure 2.3. Broad social assistance is complementing the increase in core programmes ..................... 24

Figure 2.4. Social insurance spending (public and private) is almost three times higher than social

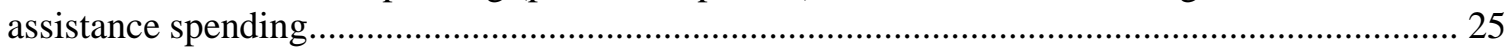

Figure 2.5. The spending gap between social insurance and social assistance has narrowed ............... 26

Figure 2.6. Social assistance has grown as a proportion of total spending ......................................... 27

Figure 2.7. Private pension and medical aid spending has risen sharply in recent years ..................... 29

Figure 3.1. Inflation has trended downwards since independence ........................................................ 34

Figure 3.2. The functional allocation of public spending has been relatively stable............................ 36

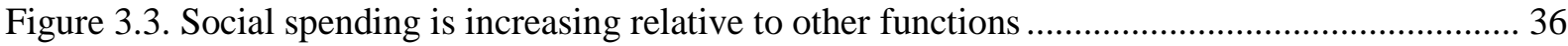

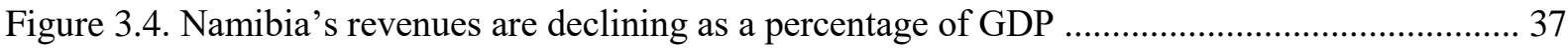

Figure 3.5. Main sources of revenue have fluctuated over time ........................................................... 39

\section{Boxes}

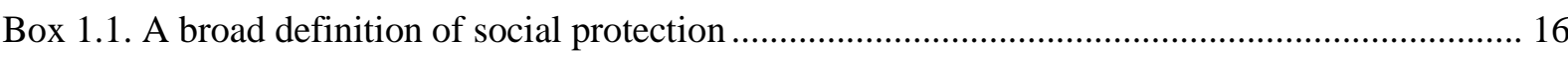

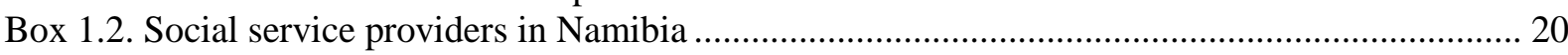

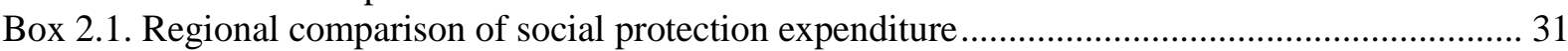

Box 3.1. Fiscal policy as a whole is key to reducing poverty and tackling inequalities ...................... 38 


\section{Abbreviations and acronyms}

$\begin{array}{ll}\text { ART } & \text { Anti-retroviral treatment } \\ \text { ECD } & \text { Early Childhood Development } \\ \text { ECF } & \text { Employees' Compensation Fund } \\ \text { FY } & \text { Financial year } \\ \text { GDP } & \text { Gross domestic product } \\ \text { GIPF } & \text { Government Institutions Pension Fund } \\ \text { GRN } & \text { Government of the Republic of Namibia } \\ \text { MGECW } & \text { Ministry of Gender Equality and Child Welfare } \\ \text { MoHSS } & \text { Ministry of Health and Social Services } \\ \text { MoPESW } & \text { Ministry of Poverty Eradication and Social Welfare } \\ \text { MSD } & \text { Maternity leave, sick leave, death benefits } \\ \text { NAD } & \text { Namibia dollar } \\ \text { NAMFISA } & \text { Namibia Financial Institutions Supervisory Authority } \\ \text { NSA } & \text { Namibia Statistics Agency } \\ \text { NSFAF } & \text { Namibia Students Financial Assistance Fund } \\ \text { PEPFAR } & \text { Presidents Emergency Plan for Aids Relief } \\ \text { pm } & \text { Per month } \\ \text { PSEMAS } & \text { Public Service Employees Medical Aid Scheme } \\ \text { RCCF } & \text { Residential Child Care Facilities } \\ \text { SACU } & \text { Southern African Customs Union } \\ \text { SSC } & \text { Social Security Commission } \\ \text { USD } & \text { United States dollar } \\ \text { ZAR } & \text { South African rand } \\ & \end{array}$




\section{Executive summary}

Namibia is an upper middle-income country that confronts severe social and economic challenges. Chief among these is the question of how to ensure that prosperity is shared more equally across the country. With a Gini coefficient of 0.57 , Namibia has one of the highest levels of income inequality in the world. The poverty rate is $17.4 \%$ and is particularly high among children. Broader measures of deprivation demonstrate problems with the reach and quality of public services. Unemployment is also very high, particularly among the youth.

The Government of the Republic of Namibia (GRN) has placed social protection at the centre of the policy response to these challenges. Social assistance has scaled up dramatically since the early 2000s, in particular the proportion of children who receive some form of cash transfer and are covered by the school-feeding programme has risen significantly. Coverage of Namibia's universal old age grant has also grown in absolute terms at the same time as benefit values have increased in real terms.

Overall, spending on social assistance increased from 1.3\% of GDP in 2000/01 to 3.5\% of GDP in 2015/16. As a proportion of public spending, it rose from $4.0 \%$ to $8.3 \%$ over the same period. In the 2017/18 fiscal year, some 170386 individuals received the old age grant while 41061 received the disability grant. The number of child grant beneficiaries stood at 344055 at the end of 2017. A significant portion of Namibia's population of 2.6 million individuals thus benefits directly from social assistance, with the number of indirect beneficiaries (members of a recipient's household or family) higher still.

Social assistance is the GRN's most effective direct mechanism for reducing poverty and inequality. Although redistribution alone cannot eliminate poverty, there is a strong case for scaling up social protection at the same time as enhancing education, infrastructure and job-creation policies as the GRN looks to achieve its target of reducing poverty to $10 \%$ by 2022 , as articulated by the Fifth National Development Plan.

However, fiscal constraints and competing public policy priorities are limiting the potential for continued growth in social assistance. Namibia is currently reducing spending in response to recent increases in its fiscal deficit and rising debt levels. Government revenue as a proportion of GDP is on a downwards trajectory, reflecting declines in transfers from the Southern African Customs Union. At the same time, public spending is needed to help the economy to escape from an extended period of weak growth, for example through significant investment in infrastructure.

The potential for other social protection interventions to reduce poverty is also limited. Namibia possesses well established social insurance arrangements but these largely cater for public sector workers. Combined spending by the Government Institutions Pension Fund and the Public Service Employees Medical Aid Scheme (PSEMAS) equated to $2.9 \%$ of GDP in 2015/16, with PSEMAS benefiting from large subsidies from general revenue to compensate for low contribution rates among civil servants. 
Discussions continue regarding the introduction of a public pension fund and medical aid scheme to increase social insurance coverage, especially among workers at lower-income levels who are often excluded from private arrangements. However, the current economic climate is not conducive to large-scale reforms in social insurance.

At the same time, spending on active labour market policies has grown, driven by financial assistance to students and vocational training. Spending on broad social protection programmes, including early childhood development, for example, have also increased. Combined spending on active labour market policies and broad social protection programmes was equivalent to $1.1 \%$ of GDP in 2015/16.

To achieve national and international objectives, the GRN needs to increase the impact of social protection without receiving higher budgetary allocations, at least in the short-tomedium term. A more systematic approach to social protection is likely to be critical in delivering the efficiencies required. Doing more with less requires better information systems, reprioritisation of resources to the most effective programmes, prioritising resilience over relief, and perhaps even merging or shutting down programmes that overlap with others or do not deliver the desired results.

At the same time, it is necessary to plug gaps or address financial imbalances in contributory arrangements that pose short- or long-term threats to their sustainability. Doing so can be a source of fiscal space in the short term and protect public finances over the longer term.

Namibia is in the process of developing a national social protection policy. It is important that this policy be accompanied by a financing strategy that reflects existing fiscal constraints but also looks beyond them. Such a strategy should incorporates a range of different scenarios for key macroeconomic variables and social protection spending to prepare Namibia's social protection system for a range of futures, for better or for worse. 



\section{Introduction}

Over nearly three decades since Namibia achieved independence from South Africa, it has enjoyed stable and robust economic growth. Since 2009, Namibia has been classified as an upper middle-income country, with an average yearly per capita income of NAD 69279 in 2016, equivalent to USD 4 710. However, not all Namibians have benefited from this success, and the country's current economic situation is not so benign.

In terms of income distribution, Namibia is one of the most unequal countries in the world, with a Gini coefficient of 0.57 in 2015/16 (Namibia Statistics Agency, 2017 $[1]$ ), down from 0.60 in 2003/04. Although poverty levels have declined significantly since independence, $17.4 \%$ of the population was classified as poor and $11 \%$ as severely poor in 2015/16 by national definitions. Broader measures of deprivation are also a concern: Namibia's human development index stood at 0.647 in 2017, ranking it $129^{\text {th }}$ of 189 countries (UNDP, 2018[2]). Some 24\% of children were stunted in 2013.

The Government of the Republic of Namibia (GRN)'s 5th National Development Plan 2017/18-2021/22 (NDP5) targets a reduction in the proportion of the population that is poor and severely poor to $10 \%$ and $5 \%$, respectively, by 2022 . Expanding the social protection system, which has already achieved important reductions in poverty and inequality since independence, is a cornerstone of NDP5 (National Planning Commission, $2017_{[3]}$.

At the same time, the goal of bolstering Namibia's existing social protection programmes is anchored in other strategic documents and policies. These include the Harambee Prosperity Plan, launched by President Hage Geingob in 2016, and the Blue Print for Wealth Redistribution and Poverty Eradication (henceforth, the Blue Print), which was published by the Ministry of Poverty Eradication and Social Welfare (also in 2016). The Blue Print calls for an extension of existing social protection programmes, the creation of new programmes targeting vulnerable individuals who are currently not covered, the establishment of food banks and guaranteed access to basic services (Ministry of Poverty Eradication and Social Welfare, 2016 $\left.6_{[4]}\right)$.

At the time of writing, the GRN is developing an official national social protection policy. Although there is clear potential for building a coherent social protection system, Namibia confronts a number of significant challenges in doing so. These include limited coverage of certain social grants (particularly those aimed at children), an absence of programmes for working-age individuals, gaps in coverage of contributory arrangements and a lack of integrated data on social protection beneficiaries. Provision is fragmented across a large number of public institutions and the absence of an overarching social protection policy contributes to a continued lack of coherence and co-ordination across the sector (Ministry of Poverty Eradication and Social Welfare, 2016 ${ }_{[4]}$ ).

There are broader structural constraints to expanding social protection, in particular through contributory arrangements. Namibia's labour force confronts extremely high levels of unemployment: the unemployment rate increased from $27.5 \%$ in 2012 to $34.0 \%$ 
in 2016. Youth unemployment (among individuals aged 15-34) rose from $37.8 \%$ to $43.4 \%$ over the same period (for those not in school or not attending higher education). Unemployment increased the most for those with no education - from $21.1 \%$ to $34.5 \%$ (Namibia Statistics Agency, 2017 $7_{[5]}$ ). Meanwhile, an estimated $66.5 \%$ of employment in Namibia is informal (Namibia Statistics Agency, 2017 $\left.{ }_{[5]}\right) .{ }^{1}$

Stronger and more inclusive economic growth is critical for addressing Namibia's three grand challenges of poverty, inequality and unemployment. Alongside investment in infrastructure and job creation, social protection policies have a key role to play in this regard. However, the fiscal space needed for higher tax-financing of social protection is limited. As a result, increased efficiency in public expenditure, reprioritisation of the budget and greater coverage of contributory schemes are essential.

This paper is intended as an empirical contribution to discussions on the financing of Namibia's social protection system and reflects the current fiscal challenges. It maps current social protection provision and financing against Namibia's social, macroeconomic and fiscal context up to 2015/16. It examines the framework under which social protection programmes are implemented and financed, as well as constraints and opportunities for enhancing financing. It concludes with recommendations for increasing the impact of social protection in a fiscally constrained environment.

This paper is also intended to serve as a basis for a financing strategy to accompany the development of a social protection policy framework. Financing strategies provide a critical framework for developing social protection systems. Such strategies focus not only on identifying fiscal space that might emerge for new spending but also on assessing current funding flows to social protection programmes and reprioritising allocations to achieve a more effective, efficient and equitable expenditure. 


\section{Mapping Namibia's social protection system}

Social protection is a broad concept referring to measures that aim to reduce poverty, vulnerability and inequality (Dempers, 2016 $6_{[6]}$ ) (see Box 1.1). Namibia currently has one of the most comprehensive social protection systems in Africa, comprising a wide range of social assistance, social insurance (including public and private arrangements) and active labour market programmes. This section provides a high-level inventory of the major social protection schemes examined in this paper.

Social assistance in Namibia includes a number of child grants, disability and old age grants, veterans' allowances as well as a range of support programmes for veterans. ${ }^{2}$ It also consists of food banks, school feeding, drought relief and funeral benefits, as well as social housing. Social welfare services are provided for children, adults and families including the provision of alternative care and residential child care facilities. These programmes are implemented by a large number of ministries and agencies.

Public sector workers enjoy comprehensive social insurance provision but there are major gaps in coverage for other workers in the absence of a statutory pension arrangement and medical aid scheme (health insurance). The para-public Social Security Commission (SSC) covers the private sector against work-related accidents and illnesses as well as maternity, sick leave and death. Unemployment insurance does not exist.

\subsection{Social assistance coverage has increased significantly since 2000}

For the purposes of this paper, social assistance is disaggregated by core and non-core programmes. Core programmes provide substantive relief for key vulnerable groups. Broad social protection programmes are seen to complement the impact of core programmes.

\subsubsection{Social assistance programmes - core}

Namibia's social assistance programmes consist predominately of cash/in-kind transfers and non-contributory pensions that target households with children in poverty, the elderly and people with disabilities. ${ }^{3}$

\section{Child grants}

Four child grants exist in Namibia, all of which are implemented by the Ministry of Gender Equality and Child Welfare (MGECW). These are the Vulnerable Child Grant (VCG), the Foster Care Grant, the Maintenance Grant and the Special Maintenance Grant.

The VCG, introduced in 2014 , is a poverty-targeted benefit payable to parents with children up to the age of 16 with an income of less than NAD 1000 per month (equivalent to approximately USD 71 as of March 2019). The other benefits are categorical in nature. The Maintenance Grant provides financial assistance to parents with 
at least one child under the age of 18 who have an income of less than NAD 1000 per month, unemployed, an old age pension recipient, or disabled.

The Maintenance Grant can also be applied to parents whose spouses are incarcerated for at least six months or more. The Special Maintenance Grant is paid to parents of children with disabilities under the age of 16 years. The Foster Care grant is a cash transfer to the assigned foster parent(s) of an orphaned child.

\section{Box 1.1. A broad definition of social protection}

A comprehensive social protection system comprises three pillars: social assistance, social insurance and active labour market programmes. Depending on country context, the composition of these pillars can vary greatly, covering a wide range of different programmes, from cash grants to subsidies for goods and services (such as food or housing) and from pensions to medical schemes. Overlaps or synergies between different pillars can also exist, while financing modalities for different programmes - a principal interest of this paper - also vary.

The OECD's Social Expenditure Database provides reliable and internationally comparable statistics on public and (mandatory and voluntary) private social expenditure at programme level. It divides spending into cash benefits (which in most OECD countries are dominated by pensions) and services (which in most OECD countries are dominated by health spending (Adema and Fron, 2019 $9_{[7]}$ ). This paper does not include health expenditure; the majority of social spending presented here would be considered as cash benefits under the SOCX classification.

Social assistance provides direct cash or in-kind transfers that are financed by the government. These payments can be means tested, whereby they are targeted at households or individuals below a certain income level, or categorical, meaning that are paid to a certain group, such as the elderly or people with disabilities. Transfers can either be conditional or unconditional; recipients of conditional transfers are expected to fulfil certain requirements, typically related to accessing health, education or labour services to qualify.

Social insurance programmes are typically financed by contributions of individuals of working age. If and when a risk against which contributors are insured materialises (such as disability or retirement), they are entitled to a benefit that is usually in proportion to their incomes and are thus of greater value than the benefits paid by social assistance. Pension schemes also fulfil an income-smoothing function, allowing individuals to save for their retirement. For individuals with low incomes and/or working in the informal sector, the government might meet some of the cost of contributions.

Active labour market policies improve the prospects of poor and vulnerable individuals in finding productive employment. They are designed to reduce skills mismatches by (re)training workers in order to meet current demand in their local job market. Labour market activation programmes usually take the form of technical and vocational education and training (TVET), but the government can also choose to employ workers during their (re)training period so as to increase their standard of living while also stimulating the economy. 


\section{Old age and disability grants}

The old age grant provides monthly assistance for all residents aged 60 and above. The disability grant is paid to people with disabilities between 16 and 59 years of age; after the age of 60 , disability grant recipients receive the old age grant. Funeral benefits are also included for all beneficiaries of the old age and disability grants; the GRN pays insurance companies monthly premiums for each beneficiary.

Prior to independence, the old age grant was highly discriminatory. While Oshivambospeaking Namibians received ZAR 55 per month on average (in nominal prices), beneficiaries of European descent received on average almost seven times that amount, about ZAR 382 per month (Schade, 2000 $0_{[8]}$ ).

\section{Veterans' support programmes}

Veterans of Namibia's liberation struggle are entitled to various support packages. These include monthly grant (the War Veterans Subvention, WVS), a one-off gratuity whose value depends on the number of years they were involved in the struggle, a one-off amount for projects of up to NAD 200000 , as well as houses and farms. The WVS amounts to NAD 2200 and is paid in addition to other benefits such as the old age grant.

\section{Adequacy of core social assistance programmes}

Among the monthly grants, the WVS provides the largest benefit per person. The old-age and disability grants provide much higher benefit levels than the child grants. In 2017, child grant beneficiaries received NAD 250 per month, old age and disability grant beneficiaries received NAD 1200 per month and veterans receive NAD 2200 per month (Figure 1.1).

\section{Figure 1.1. Social assistance benefits are largest for veterans, smallest for children}

Monthly benefit value for various grants (2017)

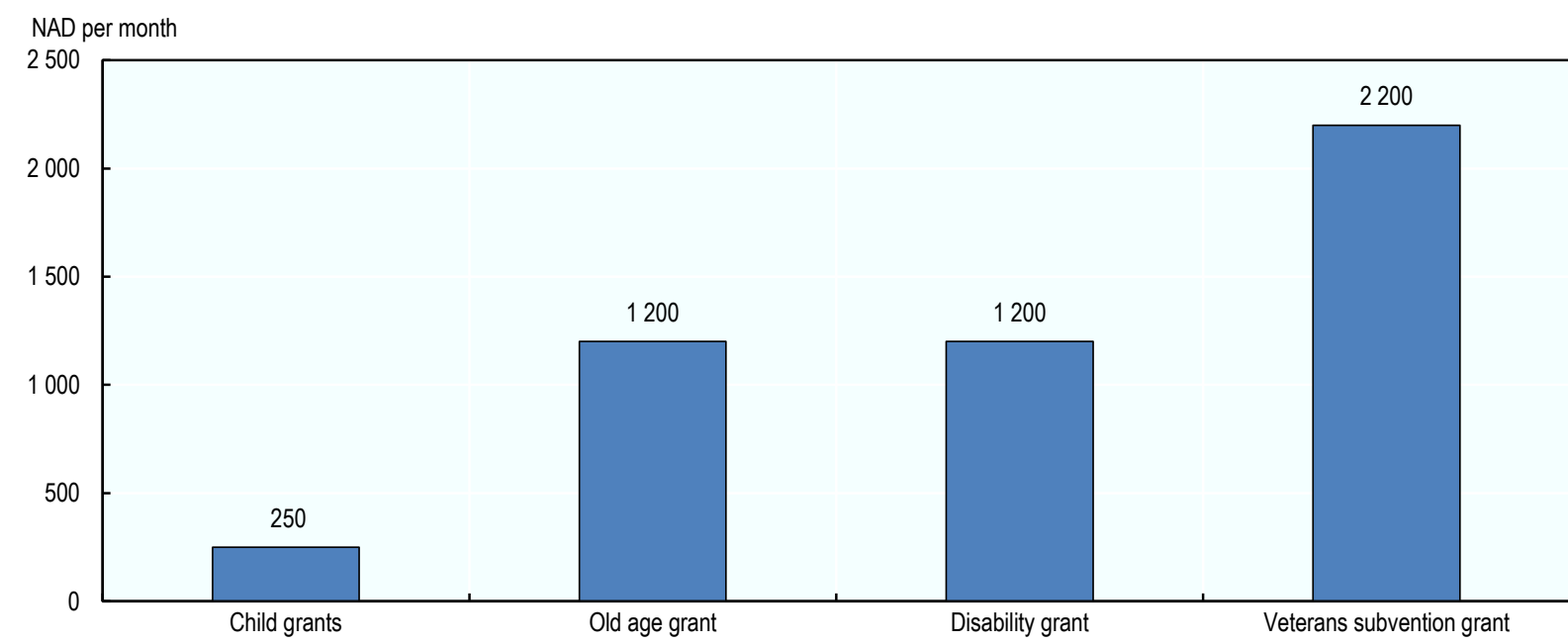

Note: As of April 2019, one United States dollar (USD) was equivalent to 14 Namibian dollars (NAD). Source: Ministry of Finance (2017 [9] $)$, Estimates of Revenue Income and Expenditure 2017-2018, available at www.mof.gov.na. 
The monthly value of the child grants has declined significantly in real terms since 2000 , having been kept at NAD 200 in current prices from 2000 to 2013. However, the benefit level was increased by NAD 50 per month in 2014. Since 2014, all eligible children in a household receive the full grant amount; previously, the second child and any further children in an eligible household only received NAD 100 per month.

Figure 1.2. Old age and disability grants have increased in real terms but child grants have declined

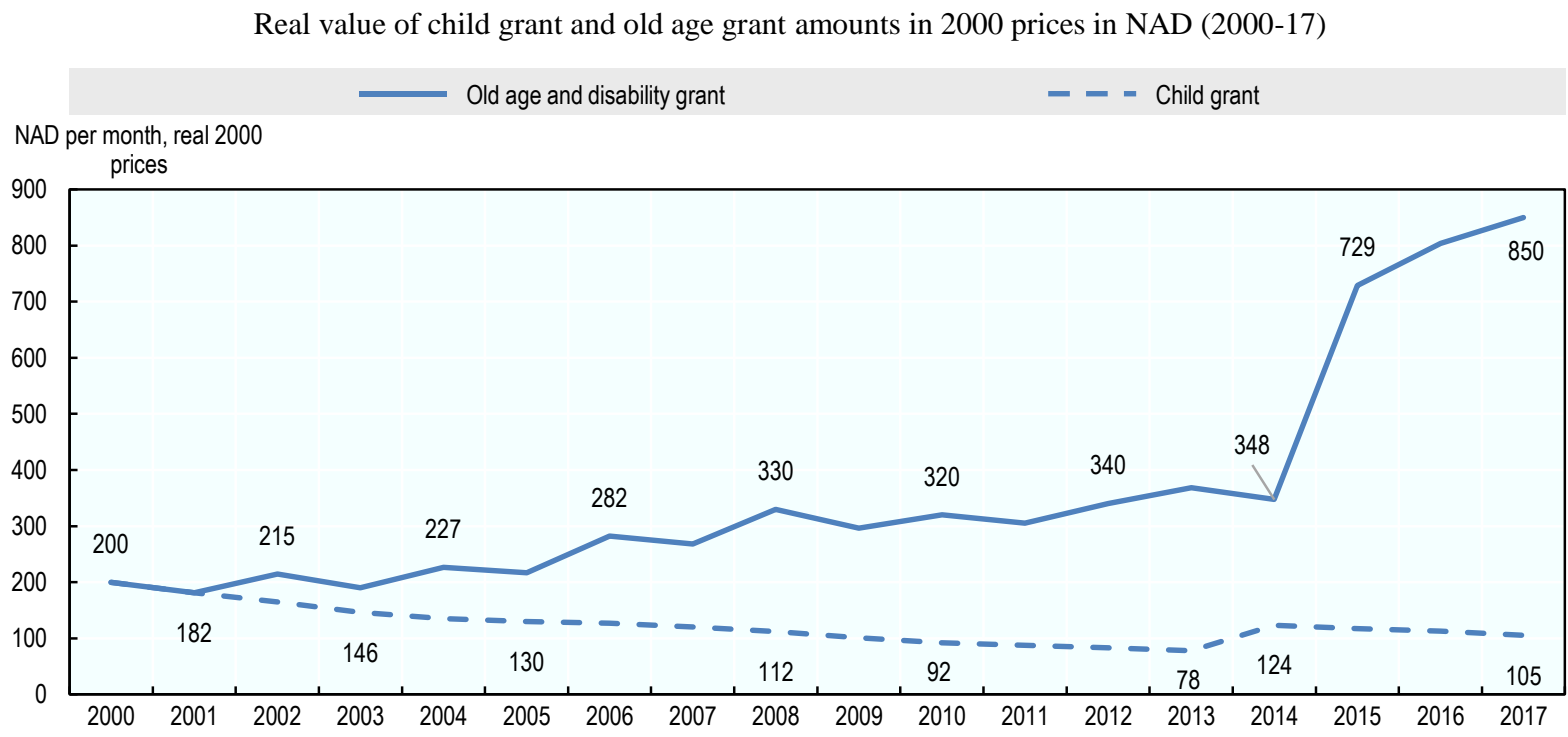

Source: Authors' calculations based on Ministry of Finance (various years), Budget Statements, available at www.mof.gov.na.

The value of the old age and disability grants has increased substantially in real terms since 2000. In 2015, the Government increased the old age and disability grants from NAD 600 per month to NAD 1000 with further increases by NAD 100 per month in both 2016 and 2017 and by NAD 50 in 2018. Pensioners have therefore seen a real improvement in their standard of living, since adjusted for inflation the monthly amount of NAD 200 per month in 2000 would have increased to NAD 586 per month in 2017 (Figure 1.2).

There has been a strong increase in coverage across the social assistance system and the combined number of beneficiaries for child grants has overtaken coverage of old age and disability grants (Figure 1.3). The number of child-grant beneficiaries increased from 4000 in 2001/02 to 344055 at the end of 2017. Meanwhile, the combined number of beneficiaries of the old age and disability grants more than doubled over the same period, from 91608 in 2000/01 to 204621 in 2016/17 and 211447 in 2017/18.

Demand for these programmes will evolve as the population ages and identification of disabilities improves. In 2015, some $43.7 \%$ of Namibia's 2.6 million population was aged 17 or under, versus $47.0 \%$ in 2000 . By 2050, that proportion is expected to fall to $31.8 \%$. Over the same period, the proportion of elderly in the population will double, with individuals aged 60 and above rising from 5.4\% in 2015 to $10.9 \%$ in 2050.

It is important to note that children are likely to be indirect beneficiaries of the old age and disability grants once these are distributed among households. Pensioners 
(particularly those in rural areas) usually transfer portions of their income between generations, to take care of grandchildren and extended family members (Levine, van der Berg and $\left.\mathrm{Yu}, 2011_{[10]}\right)$.

The value of child grants should be viewed in the context of an expansion of schoolfeeding since the programme was introduced in 2006/07. This implies that the decline of child grants in real terms has been partially offset by the provision of school meals.

Figure 1.3. Social assistance programmes are expanding coverage of children and seniors

Number of beneficiaries for selected grants (2000/01-2017/18)

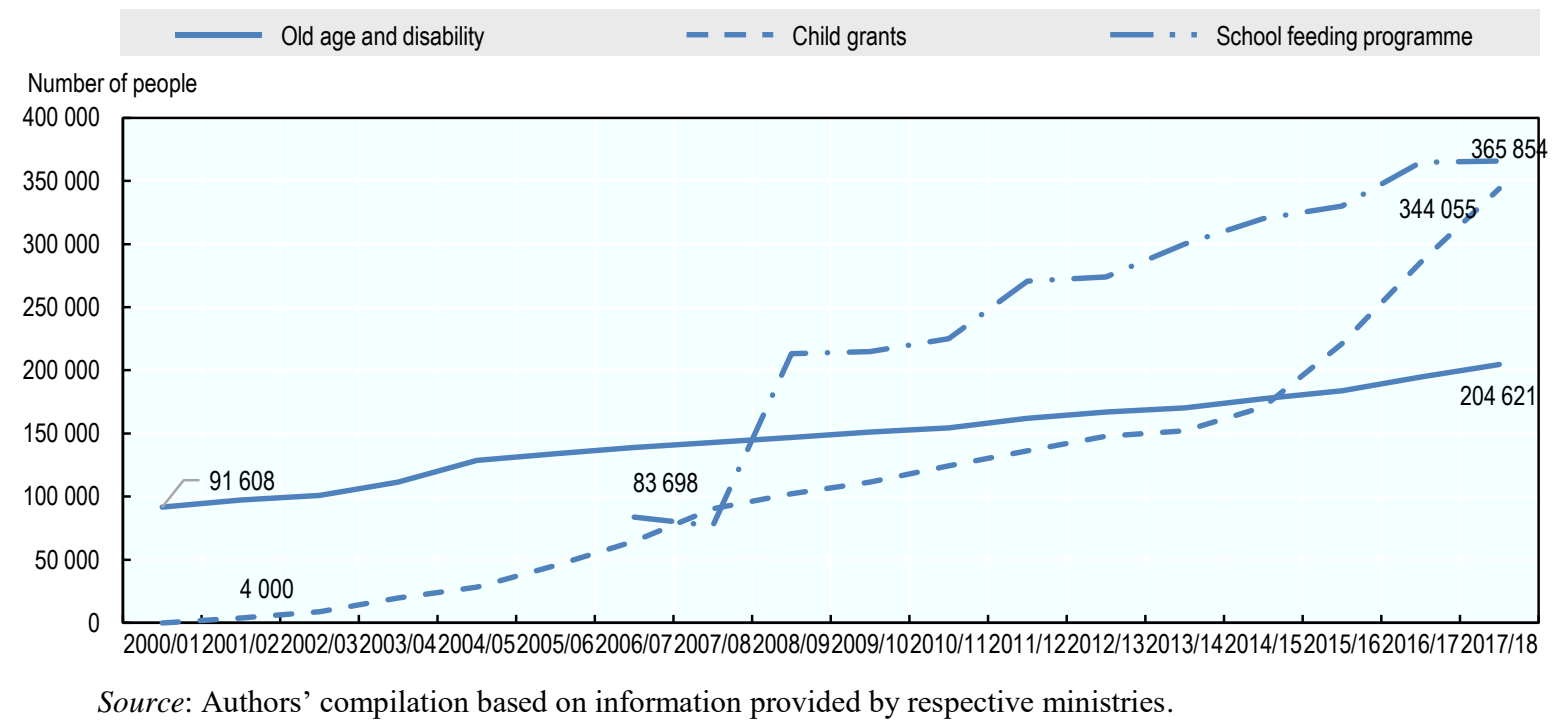

Income eligibility thresholds for the child grants are very low relative to the average wage of most recipients. For example, the Maintenance Grant and Vulnerable Child Grant threshold is set at NAD 1000 per month, well below the minimum wage of a domestic worker as well as below the value of the monthly old age and disability grants. It is also far below the threshold in South Africa, which currently stands at ZAR 3300 for singles and ZAR 6600 for couples (Westphal, 2015 $[11]$ ).

\subsubsection{Social assistance programmes - broad}

\section{Food support programmes}

School feeding programmes provide children attending pre-primary and primary schools with lunch in high-poverty areas, which are usually located in arid/semi-arid regions (Education, 2012[12]). Between 2006/07 and 2017/18, the number of beneficiaries increased from about 64000 to nearly 366000 .

In addition to the school feeding programme, the MPESW administers the Food Bank programme, which was launched in June 2016. Initially piloted in Windhoek, the programme has since expanded to six of Namibia's 14 regions as of early 2019, with nationwide coverage planned before the end of the year. At that time, around 17000 beneficiaries were receiving monthly food parcels worth NAD 550. Street committees consisting of unemployed youth are responsible for identifying vulnerable individuals to benefit from monthly food parcels and for distributing the food parcels. 


\section{Provision of housing and shelter}

The GRN has implemented various programmes to address inadequate access to housing. These programmes include upgrading informal settlements and single quarters as well as support for initiatives such as the Build Together Programme and the Shack Dwellers Federation. Since 2014, the GRN has implemented a new programme called the Mass Housing Development Programme, which is administered by the Ministry of Urban and Rural Development and is targeting the construction of 185000 houses by 2030, to be allocated to low- and middle-income residents of Namibia through the National Housing Enterprise (National Housing Enterprise, n.d.[13]).

Caregivers of vulnerable children placed by a Commissioner of Child Welfare receive a place of safety allowance worth NAD 10 per day (Ministry of Gender Equality and Child Welfare, $\left.2010_{[14]}\right)$. Women and children are eligible for shelters and government subsidies for Residential Child Care Facilities (RCCF), while elderly persons benefit from subsidies for old age homes.

\section{Box 1.2. Social service providers in Namibia}

The directorate of development social welfare services in the Ministry of Health and Social Services (MoHSS) provides social welfare services to vulnerable, marginalised and poor individuals. These services include support for old age homes, establishment of regional committees on suicide, prevention of drug abuse, as well as implementing strategies on human trafficking and migrants.

In addition to social workers employed in the directorate of social welfare services, the MoHSS employs social workers in hospitals to address the needs of in-patients including children. The cases of children that are discharged but who are still in need of support are handed over to the MGECW.

\subsection{Public sector workers receive comprehensive social insurance coverage}

Namibia's social insurance system includes pension funds and medical aid (public and private) as well as compulsory contributions to the Social Security Commission (SSC). While coverage for public-sector workers is comprehensive, there are important gaps for private-sector workers.

\subsubsection{Pension funds}

Public and private entities provide complementary coverage of retirement arrangements in Namibia. Public pensions are provided to all civil servants and employees of participating institutions through the Government Institutions Pension Fund (GIPF), which is a fully funded defined benefit scheme. GIPF members contribute $7 \%$ of their monthly basic salary to the Fund while their employer (the state) contributes $16 \%$, making a combined contribution rate of $23 \%$.

According to data from the Namibia Financial Institutions Supervisory Authority, there were 300028 active members of private pension funds in 2015, roughly four times as many as principal members of medical aid schemes. The number of active members increased at a much faster rate $(172.8 \%)$ than the number of pensioners $(24.8 \%)$. In the 
case of the GIPF, the number of pensioners dropped by $11.1 \%$, while the number of active members rose by $30.9 \%$.

Pension funds have much higher coverage than medical aid schemes. In 2014, pension fund members accounted for $58.8 \%$ of all workers, a proportion that rises to $74.8 \%$ when subsistence farmers and unpaid family workers are excluded. However, only $50.1 \%$ of all persons of the age of 60 years and older benefitted from pensions either paid by a private pension fund or the GIPF in 2015. Consequently, half of pensioners rely on the noncontributory old age grant.

\section{Medical aid}

The Public Service Employees Medical Aid Scheme (PSEMAS) has a dual purpose: (a) to assist its members with the cost of medical care; and (b) to promote the health of members through wellness and chronic disease management. Public sector employees can choose between two coverage options, for which they either contribute NAD 120 or NAD 240 per month to the PSEMAS, depending on their choice.

Outside the public service, only $24 \%$ of all workers are covered by a medical aid scheme, although this figure is steadily increasing. Once subsistence farmers and unpaid family workers are excluded from the total number of employees, the share increases to $31 \%$.

\section{Social Security Commission (SSC)}

Contributions to the SSC cover occupational injuries (the Employees' Compensation Fund, or ECF), maternity leave, sick leave and death benefits (known collectively as MSD). The contribution to the SSC amounts to $1.8 \%$ of an employee's basic salary, usually shared equally between employer and employee. The SSC contribution starts with a monthly salary of NAD 300 but is capped at a monthly salary of NAD 9000 . Hence, the monthly minimum contribution is NAD 5.40 and the maximum contribution NAD 162. Employees with an annual income below NAD 81300 are included in the ECF to which the employer contributes. However, employers can enter into special arrangements for the ECF and cover employees that earn above this threshold.

\subsection{A range of labour market activation schemes are in place}

Labour market activation schemes in Namibia include initiatives to improve educational attainment of the youth through the support of "educarers" employed in Early Childhood Development (ECD) Centres, implementation of Vocational Education and Training (VET) programmes, youth employment programmes and the employment of youth street committees for the running of food banks, loans for tertiary education students, and educational grants for veterans. Other programmes include income-generation activities for women, which involve the provision of equipment, as well as mental health counselling for the reintegration of veterans.

The GRN provides substantial assistance for tertiary education students in the form of loans through the Namibia Students Financial Assistance Fund (NSFAF). The objective is to enable students to study whose parents would otherwise not be able to afford tertiary education for their children. The loans have to be repaid once the studies are completed. Under specific circumstances, the repayment of loans can be suspended. 
Similarly, the GRN is increasing spending on VET programmes. While funds were allocated directly to Vocational Training Centres in the earlier years, they are now channelled to the National Training Authority. 


\section{Charting social protection expenditure}

As discussed in Section 1, social protection is implemented by a range of public and private institutions in Namibia. Even calculating tax-financed social protection spending based on budget documents is not straightforward. This section combines information from a range of sources to provide a comprehensive mapping of social protection in Namibia that has not been carried out before.

Since 2000, public expenditure on social protection has steadily increased as a proportion of gross domestic product (GDP) and total government spending. Total social protection expenditure, including public and private, contributory and non-contributory arrangements, increased from 8.4\% of GDP in 2002 to $12.9 \%$ of GDP in 2015/16.

Public spending on core social assistance was equivalent to $3.4 \%$ of GDP and $8.9 \%$ of total government expenditure in 2016/17 (Figure 2.1). The introduction of the Vulnerable Child Grant has been an important driver of higher expenditure in recent years. Figure 2.2 summarises aggregate social assistance and social insurance expenditure as a proportion of GDP, disaggregated by public and private spending.

Figure 2.1. Social assistance spending has increased over the last decade

Core and broad social assistance expenditure (2000/01-2016/17)

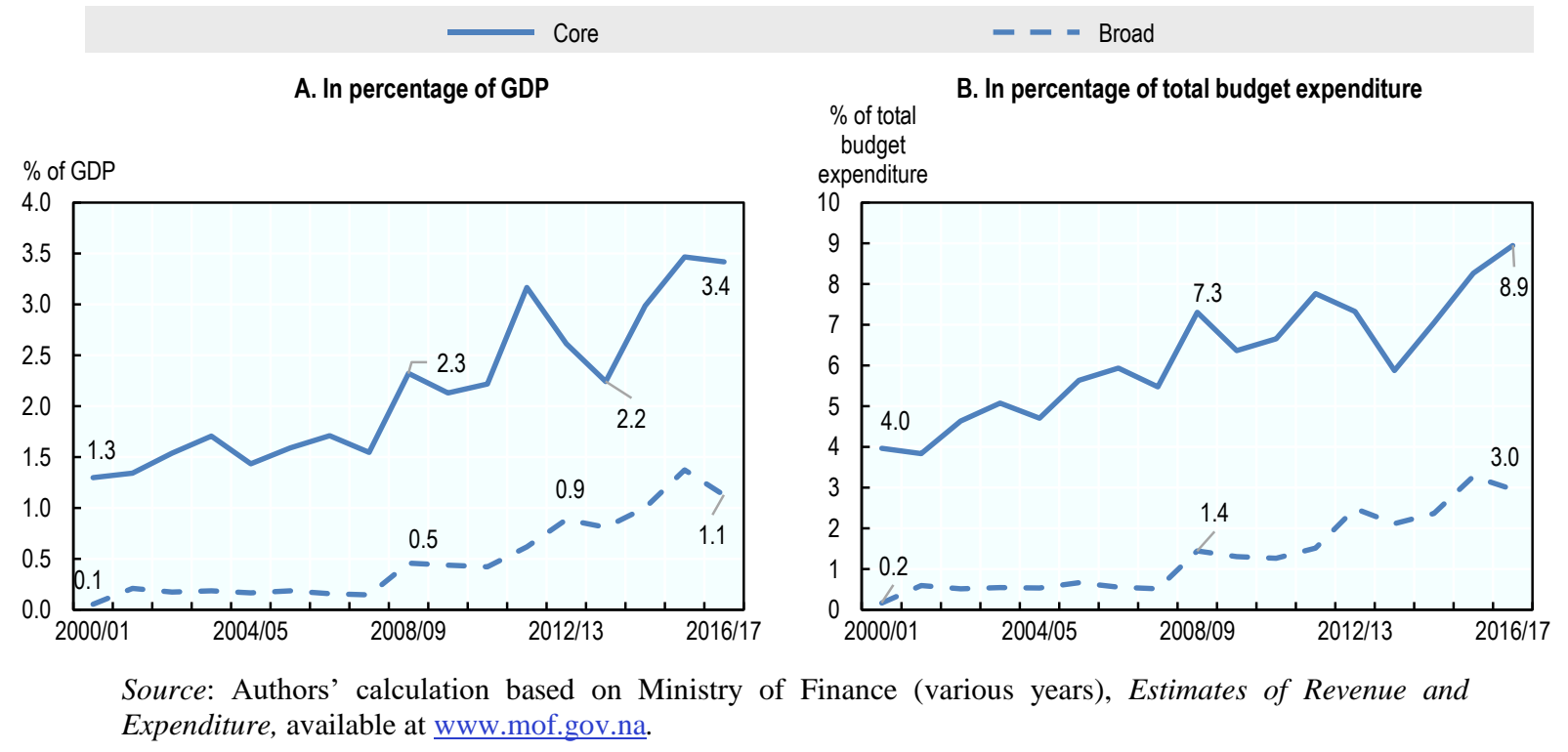


Figure 2.2. Total social protection spending is on the rise

Aggregate social protection expenditure, public and private (2002/03-2015/16)

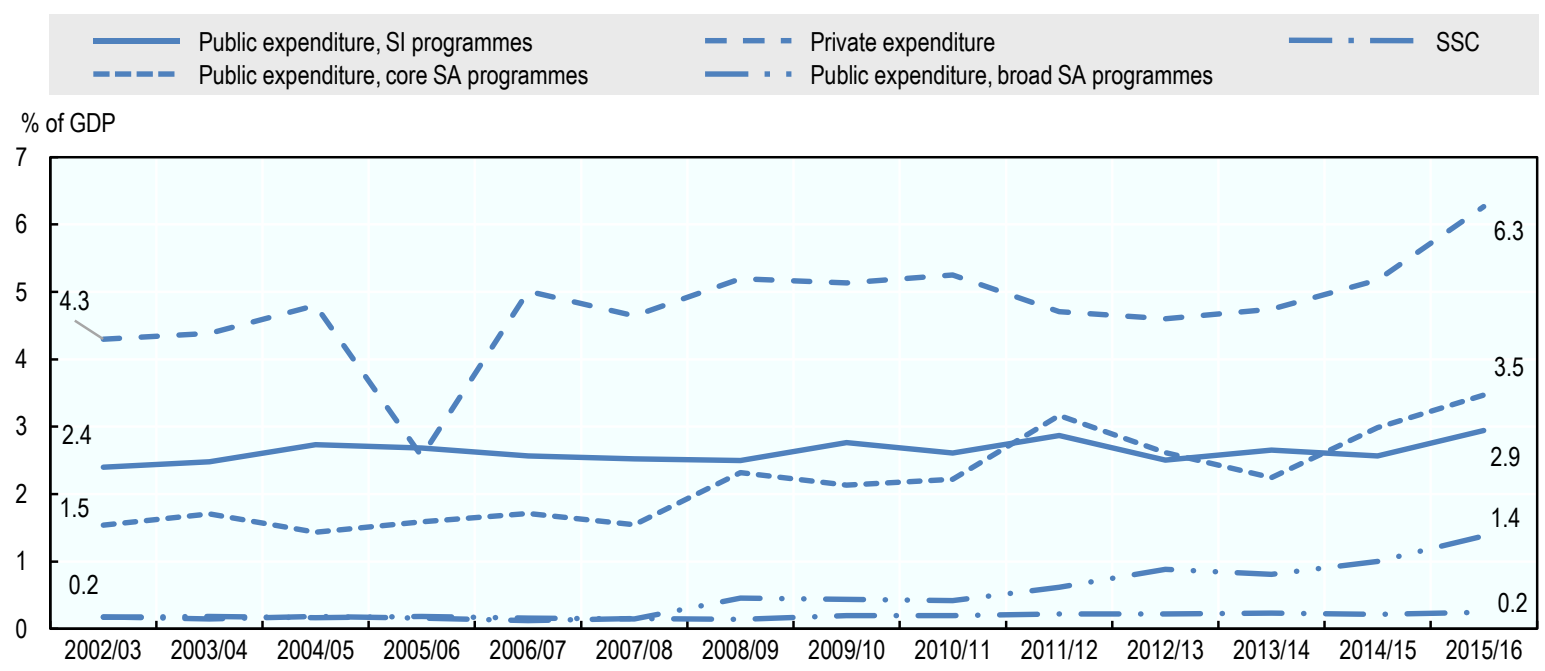

Source: Authors' calculation based on Ministry of Finance (various years), Estimates of Revenue and Expenditure, available at www.mof.gov.na.

Spending on social assistance has risen dramatically in absolute terms over the past decade due to the introduction of new programmes, increases in benefit values and broader coverage. Public expenditure on core social assistance programmes increased from NAD 345.6 million in 2000/01 to NAD 5501.3 million in 2016/17 in current prices (Figure 2.3). Spending on broad programmes has risen from NAD 15 million to NAD 1815 million over the same period, indicating an expansion of initiatives to complement direct transfers.

Figure 2.3. Broad social assistance is complementing the increase in core programmes

Budget allocation to core and broad social assistance schemes (2000/01-2016/17)

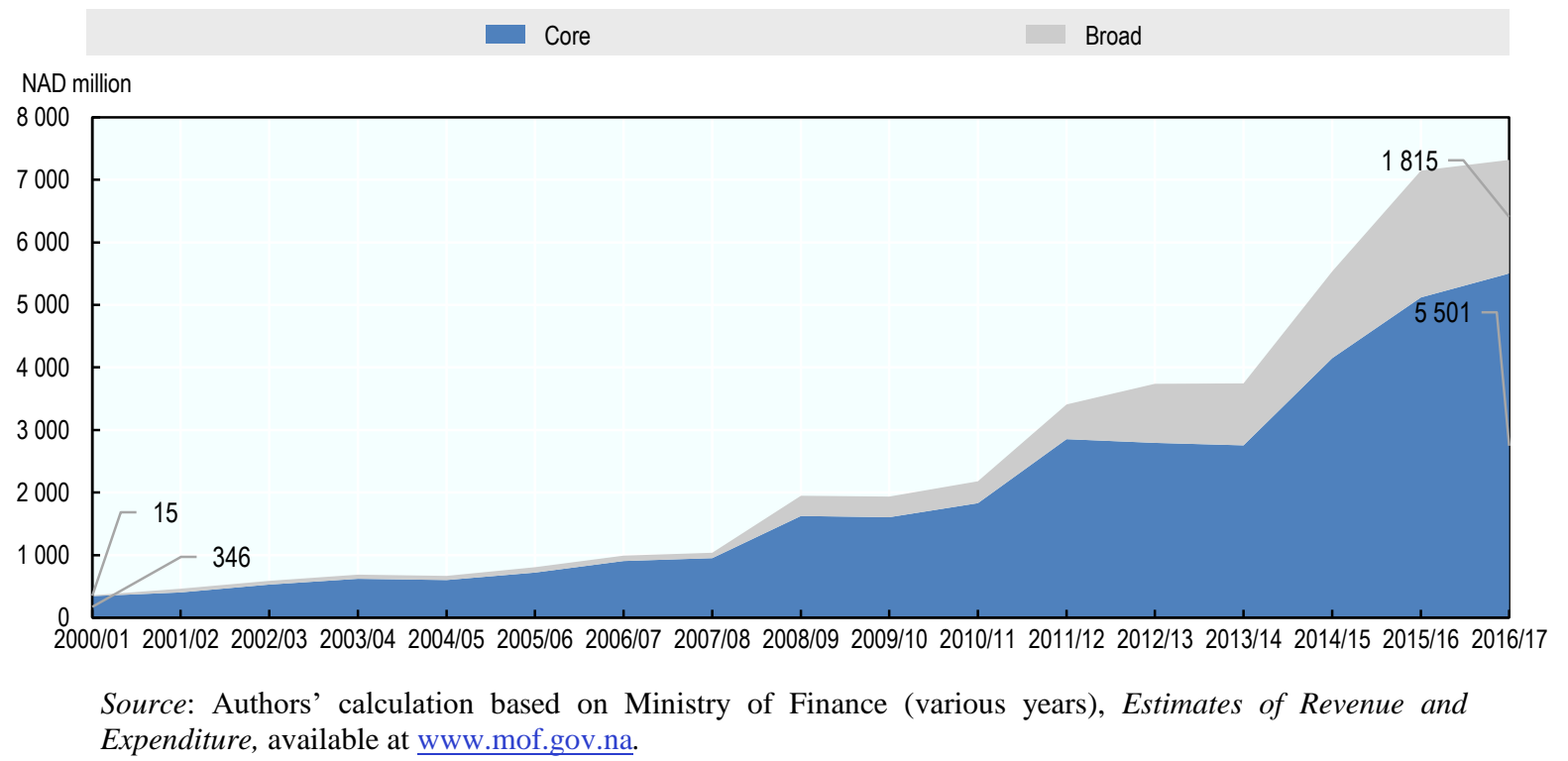


Spending on core social assistance programmes rose from 1.3\% of GDP in 2000/01 to $3.4 \%$ of GDP in 2016/17. Over the same period, per capita spending rose from NAD 188.81 to NAD 2325.42. In 2016/17, the allocation to social assistance as a proportion of total spending was more than double its level in 2000/01: $8.9 \%$ compared to $4.0 \%$.

Public expenditure on social insurance accounts for a growing proportion of consolidated government spending. Expenditure on social security, medical aid and pension funds as a proportion of GDP rose from $6.9 \%$ in $2002 / 03$ to $9.5 \%$ in $2015 / 16$. Combined expenditure by the SSC and private and public medical aid and pension schemes has been much larger than spending by core social assistance programmes since 2002/03 (Figure 2.4). However, the ratio of social insurance over social assistance programmes decreased over time, from 4.5 in 2002/03 to 2.7 in 2015/16, because of the increase in the monthly old age and disability grant as well as higher coverage of the child grants.

\section{Figure 2.4. Social insurance spending (public and private) is almost three times higher than} social assistance spending

Expenditure on public and private social insurance and core social assistance programmes, 2002/03-2015/16

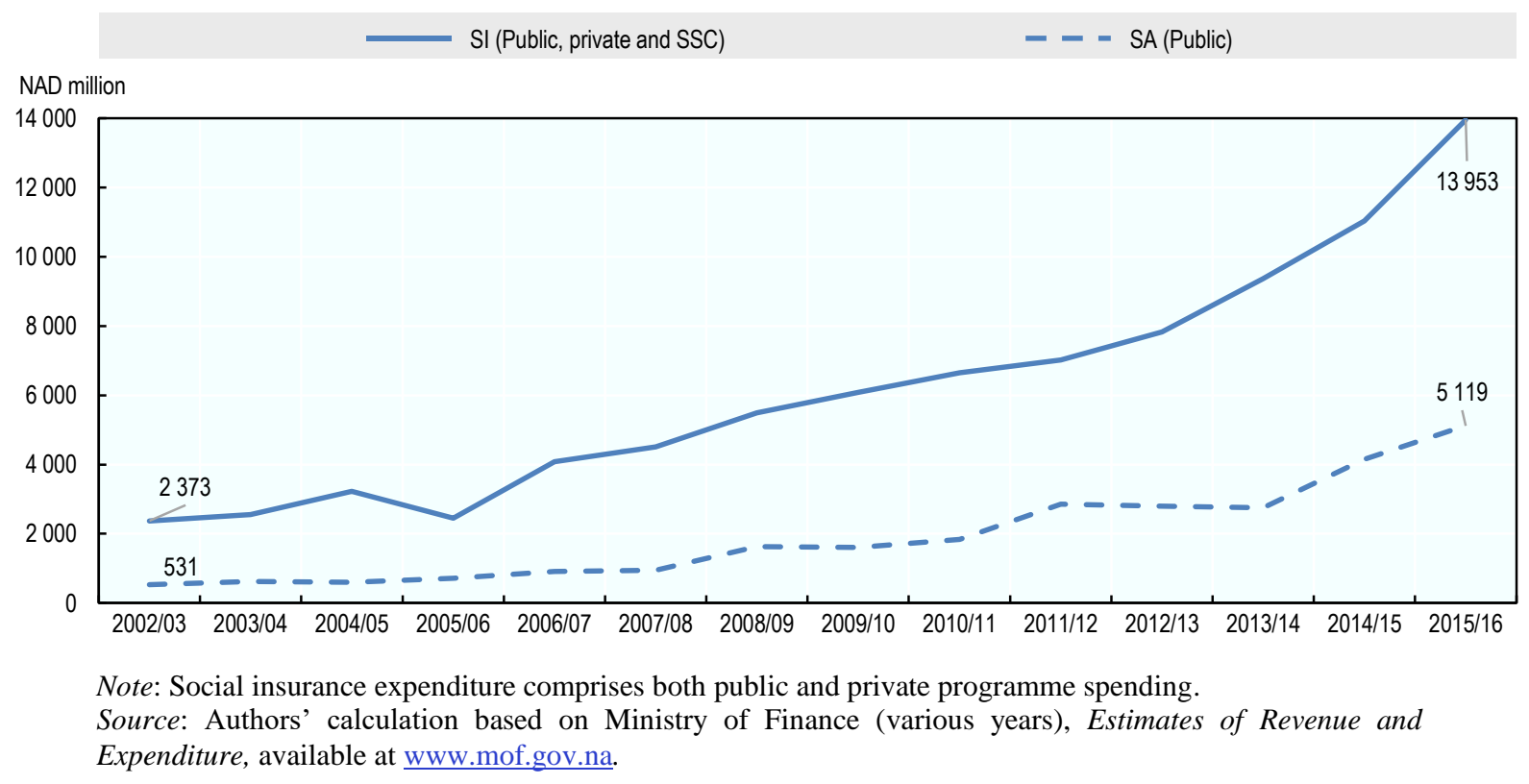

On a per capita basis, social insurance expenditure increased from NAD 1260.75 in 2002/03 to NAD 6010.08 in 2015/16. Expenditure on core social assistance programmes per capita rose faster (7.8 times) than expenditure on social insurance programmes (4.4 times) (Figure 2.5). However, social insurance spending has risen at a faster rate since $2012 / 13$.

Public spending on social protection (in current prices) registered average annual growth of $20.6 \%$ between 2000/01 and 2016/17. Per capita expenditure on all social protection programmes increased rapidly from $2002 / 03$ to $2015 / 16$. While expenditure on social assistance increased eight-fold in nominal terms, expenditure on social insurance schemes rose five-fold. Over the same period, total government expenditure per capita increased four-fold. This is a clear indication of government's efforts to address social imbalances 
reflected in poverty, unemployment and inequality, as well as a growing role for taxfinancing in overall social protection spending.

Figure 2.5. The spending gap between social insurance and social assistance has narrowed

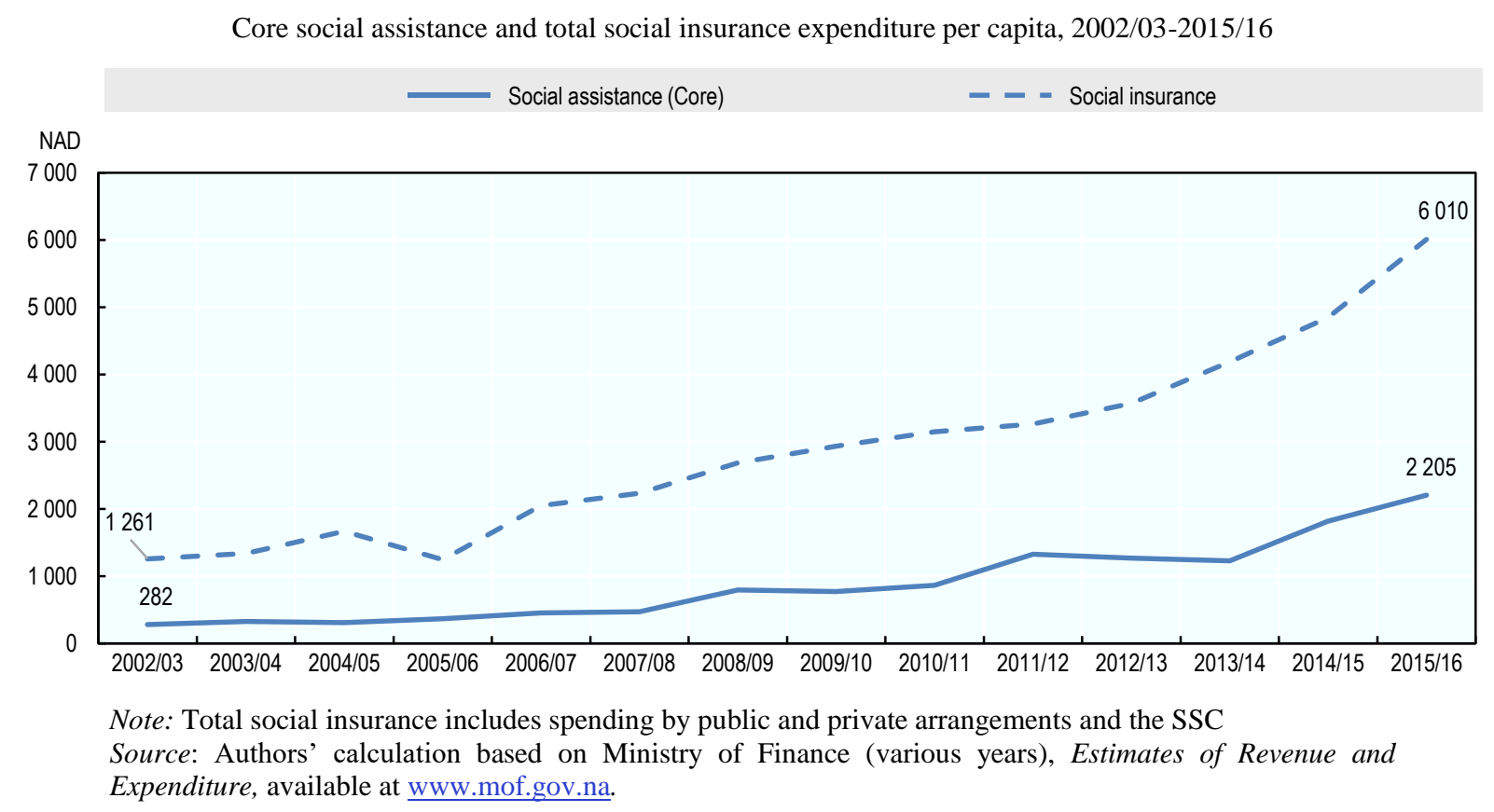

\subsection{Social assistance accounts for a growing proportion of public spending}

Core social assistance programmes absorbed $8.9 \%$ of total expenditure in 2016/17, while broad social assistance programmes accounted for $3.0 \%$ of total expenditure. Spending on core programmes increased from 1.3\% of GDP in 2000/01 to 3.4\% of GDP in 2016/17.

\subsubsection{Core}

\section{Child grants}

The combined cost of the four child grants increased from NAD 55.2 million in 2002/03 to NAD 1054.2 million in 2017/18 (nominal prices) (Figure 2.6). Administrative costs as a share of total programme expenditure increased from 2.0\% in 2003/04 to a high of $10.6 \%$ in $2011 / 12$ before declining to $6.5 \%$ in $2017 / 18$.

\section{Old age and disability grants}

As the population ages and identification of disabilities improves, the GRN is providing assistance to a larger number of elderly and people with disabilities. Old age pensions covered 170386 beneficiaries in 2017/18, an increase from 165376 beneficiaries in 2016/17. The number of disability grant beneficiaries also increased over this period, from 39245 to 41061 .

In parallel, the amount allocated to the old age grant, disability grant and funeral cover increased from NAD 270.2 million in 2000/01 to NAD 3072.9 million in 2017/18 (Figure 2.6). The share of administrative costs over total programme expenditure varied 
considerably over time, ranging from $2.4 \%$ in $2015 / 16$ to $8.5 \%$ in $2002 / 03$. In $2017 / 18$, administrative costs were estimated to absorb $1.5 \%$ of total programme costs, by far the lowest share to date. According to newspaper reports covering the tender process for grant pay-outs, the cost for registering grant beneficiaries is NAD 16 per beneficiary, while single payment costs amount to NAD 12 and double payment costs to NAD 19 (Menges, 2017 $[15]$ ).

Administrative costs per beneficiary are generally higher for old age and disability grants than for child grants. The administrative costs for the child grants amounted to NAD 167 per beneficiary in 2016/17, which is lower than in the two preceding years (NAD 231 and NAD 276 respectively). The costs for the old age and disability grant increased over the same period, from NAD 291 in 2014/15 to NAD 438 in 2016/17.

The cost differences can be explained by the different methods of payment used. The distribution of old age and disability grants is outsourced and benefits are paid in cash; child grants are transferred electronically. Although the use of means testing for the maintenance and vulnerable child grants usually increases costs, overall administrative costs remain below that of old age and disability grant pay outs.

Figure 2.6. Social assistance has grown as a proportion of total spending

Allocation to child grant, old age and disability grants, and veterans' grants (2000/01-2019/20)

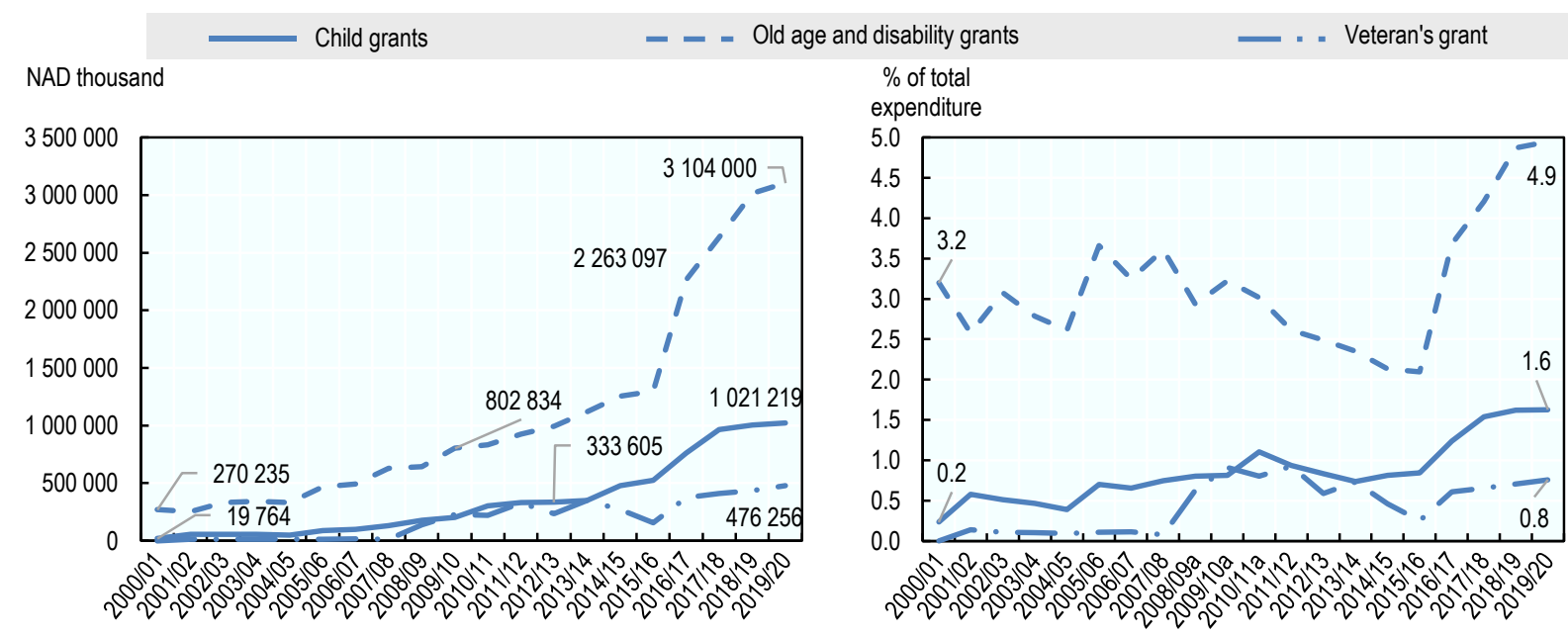

Source: Authors' calculations based on Ministry of Finance (various years), Estimates of Revenue and Expenditure, available at www.mof.gov.na.

\section{Veterans' programmes}

While expenditure on war veterans' programmes increased over the decade between 2008/09 and 2017/18, large fluctuations were recorded. Allocations increased from NAD 120 million in 2008/09 to NAD 608.9 million in 2017/18. Between these years, NAD 1162.1 million was allocated in 2011/12 and NAD 1386.4 million in 2014/15.

This volatility was due to an increase in the number of war veterans who were granted one-off gratuities for time spent in the liberation struggle and one-off payments for individual projects. War veterans who joined the struggle before 1975 received an amount 
of NAD 50000 as a one-off gratuity while those who joined after 1975 received NAD 20 000. The maximum amount for individual projects was NAD 200000.

\subsubsection{Broad}

\section{Development Social Welfare Services}

The budgetary allocation to the Ministry of Health and Social Services (MoHSS) rose from NAD 10.0 million in 2005/06 to NAD 29.8 million in 2016/17 before it declined to NAD 19.6 million in 2017/18. The National Disability Council received financial support to the amount of NAD 8.8 million in 2016/17 through the MoHSS. However, responsibility was then shifted to the Office of the President, which allocated NAD 9 million to the Council in 2017/18. This explains the declining allocation to the directorate of development social welfare services in the MoHSS. Financial support for old age homes remained fairly stable over the years at about NAD 1.4 million annually.

\section{Other programmes}

The total budgetary allocation for the school feeding programme amounted to NAD 131 million in 2017/18, which translates into NAD 1.85 per child per school day. The amount is not sufficient to provide learners with a healthy, nutritious meal. It is also significantly lower than the daily catering costs per boarder in primary and secondary school hostels, which range between NAD 25 and NAD 31 per learner.

Allocations to the pilot food bank programme declined from NAD 143.3 million in $2016 / 17$ to NAD 102.5 million in 2018/19.

Since Namibia is prone to regular droughts, the GRN runs drought-relief schemes, in particular for communal farmers. Spending on drought relief is closely linked to climate conditions. The GRN spent NAD 677.4 million in 2015/16 (a year of severe drought), compared with NAD 85.9 in 2014/15 and NAD 198.0 in 2016/17.

Budgetary allocations to shelter programmes increased strongly from NAD 3.5 million in $2015 / 16$ to NAD 21.5 million in 2017/18. The GRN provided subsidies to 22 RCCF that benefited 605 children. In addition, it provided subsidies of NAD 1.43 million to old age homes in 2016/17.

The Mass Housing Scheme programme was suspended in 2015 because of irregularities and sub-standard work. The costs of the social housing programme had increased sharply, from NAD 72.5 million in 2012/13 to NAD 503.5 million in 2015/16.

\subsection{Private-sector social insurance spending is growing strongly}

Expenditure by contributory public social protection programmes (PSEMAS, the GIPF and SSC) increased from $2.4 \%$ of GDP in 2002/03 to 2.9\% of GDP in 2015/16. Combined expenditure by private contributory programmes (private medical aid and pension funds) exceeded spending by public social insurance programmes, rising from $4.3 \%$ to $6.3 \%$ of GDP over the same period (Figure 2.7). 
Figure 2.7. Private pension and medical aid spending has risen sharply in recent years

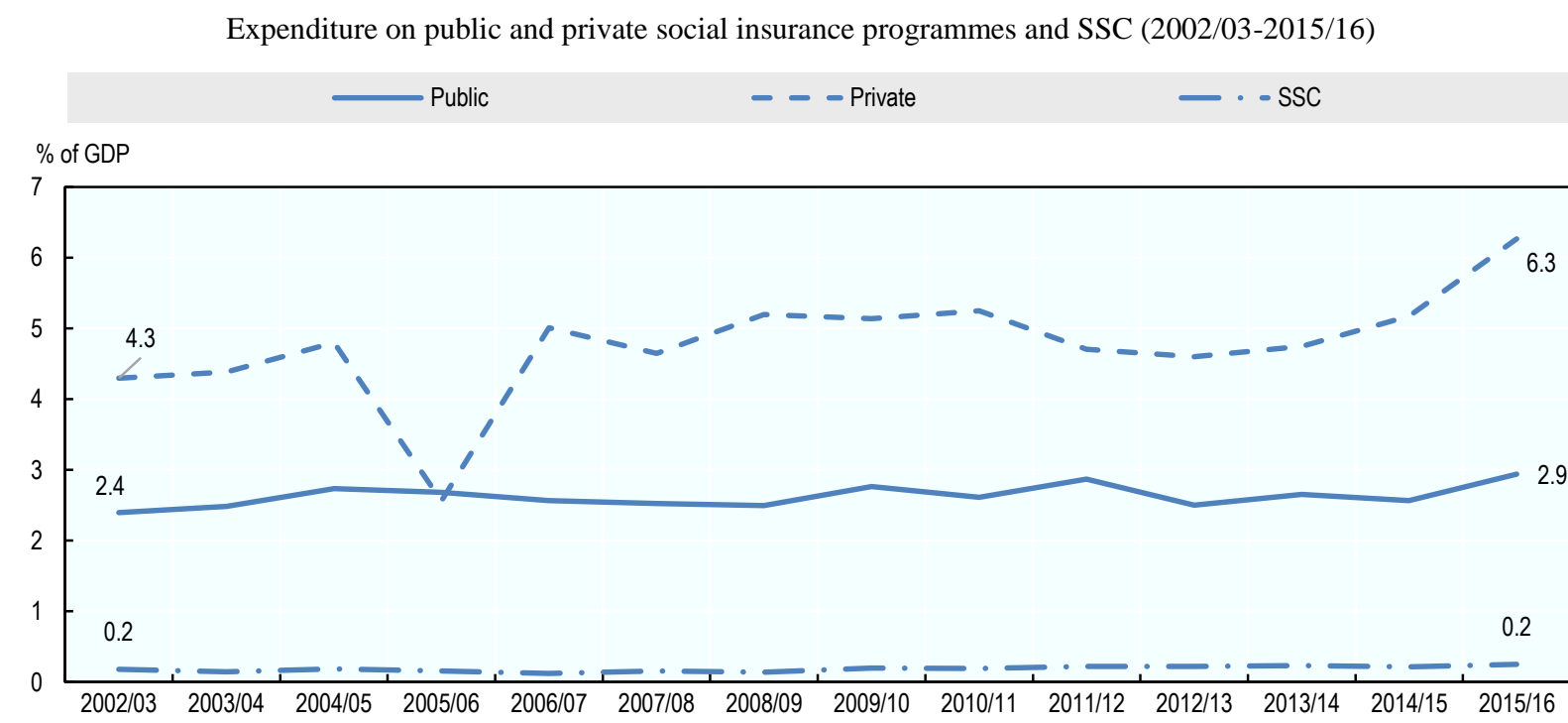

Note: Expenditure on private pensions is missing for 2005/06.

Source: Authors' calculation based on Ministry of Finance (various years), Estimates of Revenue and Expenditure, available at www.mof.gov.na.

\subsubsection{Pensions}

In 2015, the GIPF had 94397 active members that contributed a total of NAD 3257.8 million, or about NAD 34511 on average. On average, 31764 pensioners claimed NAD 65061 in benefits, which totalled about NAD 2066.6 million. Between 2000 and 2015, the average contribution outgrew the average benefit received by pensioners: contributions increased by $295 \%$ and benefits by $139 \%$. Between 2000 and 2015, the average contribution rose from NAD 8742 to NAD 34511 in current prices. The average benefit rose from NAD 27212 to NAD 65061 over the same period.

In the case of private pensions, contributions by active members increased by $20.1 \%$ between 2007 and 2015 while average pensions increased by $172.8 \%$. There was a particularly strong increase in pension spending over the second half of this period: between 2007 and 2011, expenditure grew 7\% per year on average, while between 2012 and 2015 it increased by $31 \%$ per year on average (in nominal terms).

\subsubsection{Medical aid}

Tax revenues are financing a large (and growing) financing gap in PSEMAS. The contribution of public sector employees to PSEMAS increased from NAD 41.9 million in 2000/01 to NAD 355.4 million in 2017/18. Over the same period, the GRN's contribution to PSEMAS rose from NAD 252.9 million to NAD 2534.0 million (current prices). While the GRN has to cover a rising share of medical aid costs, the contribution of public servants to total costs fell from $16.6 \%$ to $14.0 \%$.

The implicit contribution rate of public sector employees is threatening the sustainability not only of the PSEMAS but also public finances as a whole. In 2016/17, the implicit contribution rate (calculated as employee contributions as a proportion of total personnel expenditure divided by total number of filled positions) was $1.9 \%$. Flat rate contributions 
are also regressive, as they place a higher burden on low-income earners in the public sector than on high-income earners.

A number of employers in the private sector offer their employees medical aid and enrolment in a private pension funds. In 2015, private medical aid funds counted 77109 principal members and, including their dependants, a total of 186838 members. Principal members contributed NAD 3001.6 million in 2015 to medical aid funds, which amounts to an average contribution of NAD 38927 per annum. In comparison, the average civil servant contributed NAD 2820 in 2015 to PSEMAS. Principal members of private medical aid schemes claimed on average NAD 32523 compared to NAD 20490 per public servant.

Over the period from 2006 to 2015, the average contribution per principal member increased by $136.2 \%$ while the average claim increased by $137.7 \%$. The average contribution per public servant rose over the same period by $194.2 \%$, while their claims rose by $190.7 \%$.

\subsubsection{Social Security Commission}

Enrolment in the SSC has grown strongly. The number of contributing members to maternity leave, sick leave and death benefits (MSD) increased from 294610 in 2008 to 611108 in 2016. Some 16026 members received benefits in 2016: 81.2\% of this number received maternity benefits, $11.3 \%$ sick leave benefits and $7.5 \%$ death benefits. In 2014, 46877 members contributed to the Employees' Compensation Fund (ECF), while $3610(7.8 \%)$ claimed benefits from the Fund. The ratio of members claiming benefits has remained fairly stable at around $3.5 \%$.

Total contributions to the SSC amounted to NAD 550.3 million in $2016 / 17 ; 24.7 \%$ of the amount was contributed to the ECF (NAD 135.7 million) and $75.3 \%$ or NAD 414.7 million for MSD. The GRN contribution to these funds to cover public service employees was equivalent to $17.9 \%$ of total contributions. Total administrative costs amounted to NAD 296.1 million in 2016 (NAD 57.5 million for ECF and NAD 238.6 million for MSD) and thus exceeded the amount of total benefits paid out (NAD 217.2 million).

The administrative cost of providing benefits by the SSC increased from NAD 255.75 per member in 2010/11 to NAD 336.41 in 2015/16. The administrative costs of benefit payouts per contributing member exceeded the benefits per member over most of this period.

\subsection{Labour market activation and broad social protection programmes}

Allocations to the Namibia Students Financial Assistance Fund (NSFAF) increased from NAD 43.8 million in 2001/02 to NAD 962.5 million in 2017/18, indicating the importance the GRN attaches to higher education for students from disadvantaged backgrounds. Some 12000 students benefitted from the NSFAF in 2008 and about 21000 in 2013. However, NSFAF faces substantial challenges with the repayment of loans because records from transactions in earlier years of the programme were not properly maintained.

Funding for vocational training centres has grown from NAD 14.6 million in 2000/01 to NAD 382.3 million in 2017/18. These figures exclude private-sector contributions through the Vocational Education and Training levy (VET levy). 
Support for ECD Centres fluctuated over the earlier years but has increased consistently since 2009/10. Some NAD 1.8 million was allocated to ECD in 2001/02, which declined to NAD 0.4 million in 2009/10. Since then the allocation has increased steadily, to NAD 28.2 million in 2017/18.

The same division in the MGECW that handles ECD support has also supported incomegenerating activities by women since 2014/15. Funding was the same (in nominal terms) in 2017/18 as it was in 2014/15, at NAD 5.7 million.

The youth employment scheme under the Ministry of Urban and Rural Development has received NAD 3 million annually since 2012/13. With the introduction of the food bank, the GRN established street committees responsible for the identification of vulnerable households and the distribution of the food parcels in order to create employment opportunities for the youth. The costs for the street committees increased from NAD 3.6 million in the first year (2016/17) to an estimated NAD 8.7 million in 2017/18.

A once-off amount of NAD 25.5 million was allocated in 2013/14 to mental counselling for war veterans, while NAD 3 million was allocated in 2017/18.

The total allocation to broad social protection programmes increased from NAD 14.6 million in 2000/01 to NAD 1547.6 million in 2017/18. Broad social protection programmes absorbed $0.2 \%$ of the national budget in 2000/01, which increased over time to $3.0 \%$ owing to the expansion of financial assistance to students and vocational training. Over the same period, expenditure as a proportion of GDP grew from $0.1 \%$ to $1.1 \%$.

\section{Box 2.1. Regional comparison of social protection expenditure}

In general, social protection expenditure in sub-Saharan Africa is low in global comparison, averaging about $2.8 \%$ with huge variations between countries (World Bank, 2012 $[16])$. This is far below other regions such as Western Europe (18.0\%), Central and Eastern Europe (14.1\%), and North Africa (11.0\%). The World Bank concludes that national coverage of programmes is fiscally affordable, such as extending health insurance nationally in Rwanda, which has cost about $1 \%$ of GDP (World Bank, 2012 ${ }_{[16]}$ ). In comparison, the GRN spent $1.3 \%$ of GDP on subsidies for PSEMAS in 2016/17, to the benefit of public sector employees only.

A similar study on Botswana* estimates the costs of social protection at $6.1 \%$ of GDP in 2009/10 and 4.4\% of GDP in 2012/13 (Tesliuc et al., 2013 ${ }_{[17]}$ ). Excluding private arrangements, social protection spending in Namibia is of a similar magnitude, namely 5.5\% and 5.8\% in 2009/10 and 2012/13 respectively. ILO estimates that South Africa redistributes about $3.5 \%$ of GDP through social assistance programmes (Westphal, $\left.2015_{[11]}\right)$. Again, this is close to $3.4 \%$ of GDP spent on core social assistance programmes by Namibia in 2016/17. Excluding the costs for the administration of these programmes from the calculation would yield a share of 3.0\% for Namibia.

* Public pensions, social safety nets, labour market activation programmes, and scholarships were covered in this report, with the exception of private medical aid and pension fund contributions. 



\title{
3. Social protection in Namibia's fiscal framework
}

\begin{abstract}
Namibia's social protection system is one of the most comprehensive in Africa and is the GRN's most direct mechanism for reducing poverty and inequality. There is a strong investment case for increasing the breadth and/or depth of social protection in order to achieve the GRN's medium- and long-term policy objectives. However, the current fiscal context is not favourable to such an expansion.

Since October 2016, the GRN has introduced budget cuts to consolidate public finances amid a slowdown in economic activity. This section examines recent macro-economic trends and fiscal policy to better understand the fiscal space available to scale up social protection. Mindful of the competing priorities confronting the GRN, it adopts a wholeof-government approach that not only examines social protection within the context of total public spending but also analyses overall trends in public revenues.
\end{abstract}

\subsection{Economic growth has stalled in recent years}

Namibia is shifting away from a dependence on primary industries and cultivating a diversified secondary sector. Due to significant investment in the development of new mining deposits and public infrastructure projects, the labour-intensive construction sector boomed in recent years. The end of this boom contributed to a technical recession in 2016, from which the economy has not yet recovered, putting pressure on public finances. The economy contracted in 2017 (by 0.8\%) and is expected to have shrunk again in 2018, although a mild recovery is expected in 2019.

Although Namibia benefits from its Common Monetary Area (CMA) membership, ${ }^{1}$ the CMA also restricts its monetary policy, for example as a tool to support the country's industrialisation process. ${ }^{2}$ The Namibian dollar (NAD), like the currencies of Eswatini and Lesotho, is pegged one-to-one to the South African rand (ZAR). Monetary policy is therefore determined by South Africa and trends are largely driven by global economic developments (in particular international commodity prices) or South Africa's domestic situation rather than being aligned to Namibia's needs. Periods of a strong depreciation (such as during the late 1990s and early 2000s) have been followed by periods of strong appreciation (such as from 2003 to 2005 and in the years following the global financial crisis of 2008).

Inflation has declined steadily over the past three decades (Figure 3.1). The inflation rate (as measured by the consumer price index) fell from an average of $10.3 \%$ during the first decade after independence to $7.4 \%$ during the next decade and to $5.4 \%$ since 2010 . 
Figure 3.1. Inflation has trended downwards since independence

Annual (year-on-year) percentage change of the inflation rate

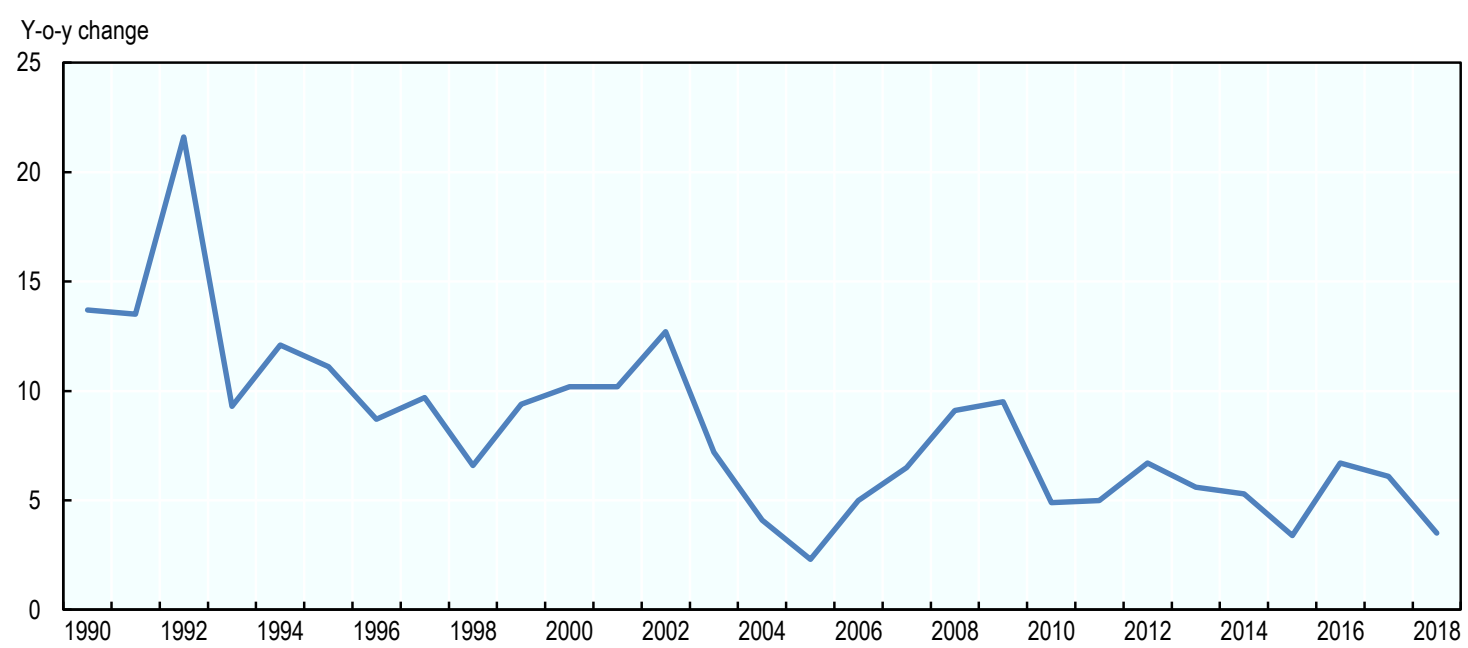

Note: Average consumer prices, as opposed to end of year prices.

Source: IMF (2018 $\left.{ }_{[18]}\right)$, World Economic Outlook, April 2018, International Monetary Fund, Washington DC.

Total public debt rose beyond a target of $35 \%$ with the issuance of a second Eurobond in 2015 to $40.1 \%$ of GDP and increased further to $42.1 \%$ of GDP in 2016/17. It is expected to have increased slightly in 2018 due to the contraction of the economy. Prior to the issuance of USD-denominated Eurobonds, the GRN used to borrow predominantly on the domestic market. Foreign debt is expected to account for $39.7 \%$ of total public debt in 2017/18. Namibia's investment rating was changed to below investment grade during the second half of 2017 in response to growing debts, weaker economic growth and low foreign exchange reserves.

The current economic and fiscal situation has reduced the fiscal space available to the GRN to stimulate economic growth and increase social sector funding. Increased efficiency in government expenditure and discussions on possible reprioritisation of the budget on social sectors (including social protection programmes) to alleviate poverty will be crucial. At the same time, expenditure on economic infrastructure is vital in order to create business and job opportunities and to generate growth overall.

\subsubsection{Employment}

Agriculture and services account for the majority of employment in Namibia. The agriculture and fishing sector accounted for the largest share of the labour force, despite suffering losses of more than nine percentage points between 2014 and 2016 due to severe droughts (29.5\% in 2014 to $20.1 \%$ in 2016). The majority of job losses occurred in communal areas, in which a disproportionately large share of poorer farmers and fishers make their livelihoods. ${ }^{3}$

The second-largest employer is the wholesale and retail trade sector, which accounts for $9.7 \%$ of the total workforce (65 500 employees), followed by the construction sector (63 000 jobs). The hospitality sector added almost 19000 jobs between 2014 and 2016 to become the fifth-largest employer, followed by the manufacturing sector (which added almost 16000 jobs over that period). 
Although the unemployment rate remains high, estimated at about $34 \%$ in 2016, job creation appears to have picked up. When members of the informal sector are excluded, namely subsistence farmers and unpaid family workers, total employment increased by 4.7\% between 2014 and 2016 to 583223 (NSA, 2016 ${ }_{[19]}$ ).

Namibia's reliance on natural resources hinders the expansion of sustainable livelihoods. The mining sector is capital intensive and employs few workers relative to the value of its output. Subsistence farming is the largest employer (including self-employment) but productivity and yields are low and hence poverty in rural areas is rife. The structure of the economy also constrains government revenue, since the tax burden is placed on relatively few formal sector employees and companies.

Low and fluctuating levels of employment underline the need to bolster the social protection system to shield individuals from the social risks of unemployment or underemployment, especially in the absence of an unemployment insurance fund. High unemployment also restricts the GRN's ability to increase coverage of social insurance, meaning that social protection continues to rely heavily on tax financing and lacks counter-cyclical mechanisms.

It is important to note that GRN revenue depends not only on economic activity in Namibia but also among its neighbours in Southern Africa, particularly South Africa. This reflects Namibia's reliance on transfers from the Southern African Customs Union (SACU) and its Common Revenue Pool. As well as facilitating free trade within Southern Africa, SACU applies a common external tariff on imports from the rest of the world, revenues from which are pooled (along with excise revenues) and redistributed amongst member states according to a revenue-sharing formula that depends in part on member countries' development needs (Southern African Customs Union, 2019 ${ }_{[20]}$ ).

\subsection{Fiscal policy is undergoing a process of consolidation}

The GRN pursued an expansionary fiscal policy for a number of years after the global financial crisis but is currently undergoing a process of consolidation. The need for such a process is magnified by an expected decline in revenue in the coming years. When combined with the rise in debt levels and low economic growth, the prospects of Namibia generating fiscal space over the medium term are not positive.

After independence, Namibia adopted a prudent fiscal policy, targeting a budget deficit no greater than $3 \%$ of GDP and total government debt at 25\% of GDP. These targets were raised in 2009/10 to 5\% and 30\% respectively, providing space for higher spending in response to declining aggregate demand and lower commodity prices.

The targets for fiscal deficit and public debt were adjusted further upward two years later, to $7 \%$ and $35 \%$ of GDP respectively. In 2015/16, the budget deficit was well above target, at $8.3 \%$ of GDP. Spending cuts and an uptick in revenue reduced the fiscal deficit to an estimated $5 \%$ in $2017 / 18$ but it is expected to increase again in the coming years (IMF, 2018[21]).

\subsubsection{Government expenditure}

Allocations to key ministries have been relatively stable in recent years (Figure 3.2). Namibia's state budget for 2017/18 amounted to NAD 62.5 billion, a nominal increase of $1.7 \%$ from the previous fiscal year. In real terms, the budget in 2017/18 was contractionary, due to an inflation rate of $6.7 \%$ in 2016. 
Figure 3.2. The functional allocation of public spending has been relatively stable

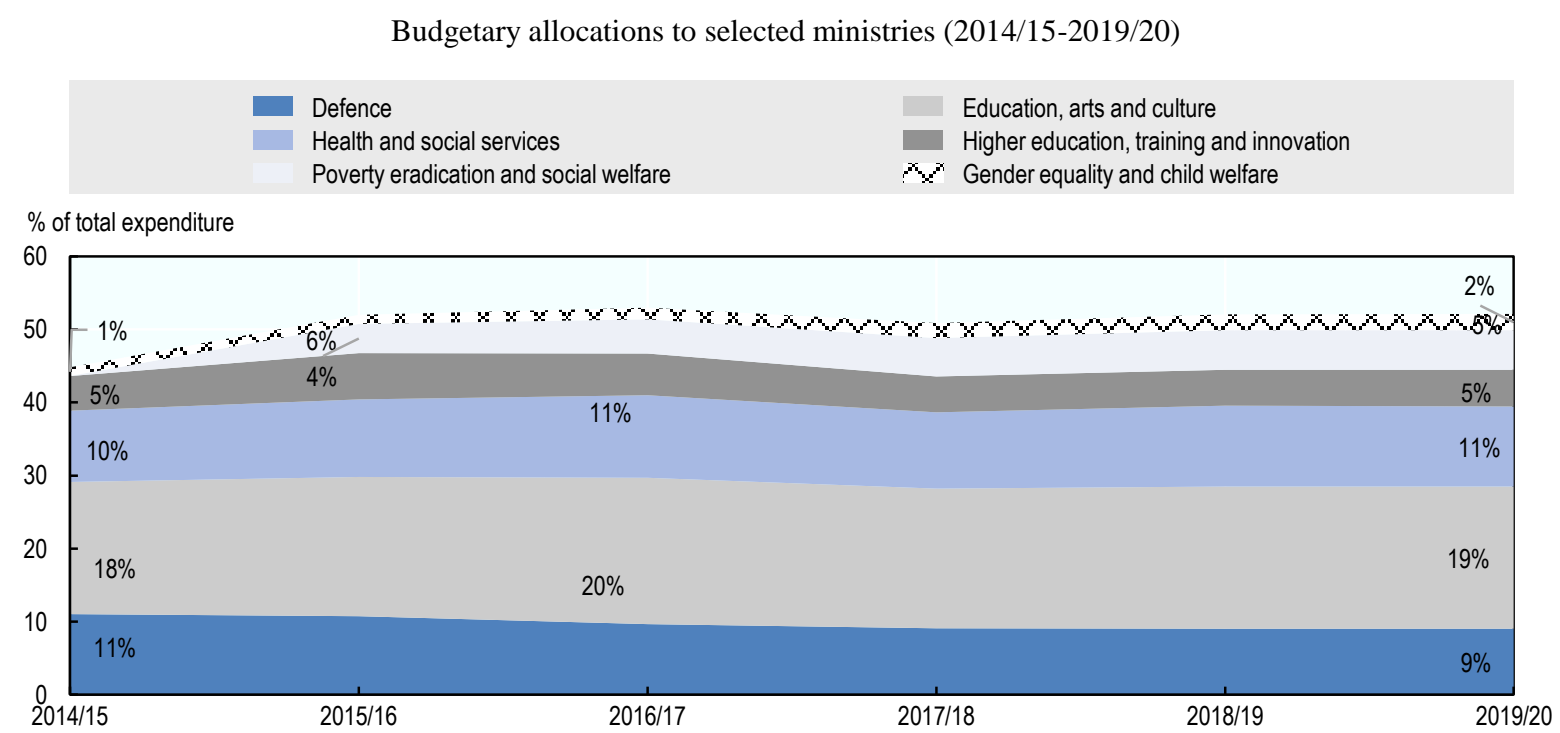

Source: Authors' calculation based on Ministry of Finance (various years), Estimates of Revenue and Expenditure, available at www.mof.gov.na.

Recent cuts to capital budgets have had an adverse impact on revenue and job creation in the infrastructure sector. The infrastructure sector reported a steep decline in budget allocations, decreasing from about $16 \%$ of total spending in 2015/16 to below $8 \%$ two years later (Figure 3.3). The share of other expenditure items has remained stable over this period. Such cuts are not sustainable in the long run; investment in infrastructure is vital for attracting private sector investment that leads to poverty alleviation by way of job creation and generation of income.

Figure 3.3. Social spending is increasing relative to other functions

Budgetary allocation to five main functions of government (2013/14-2019/20)

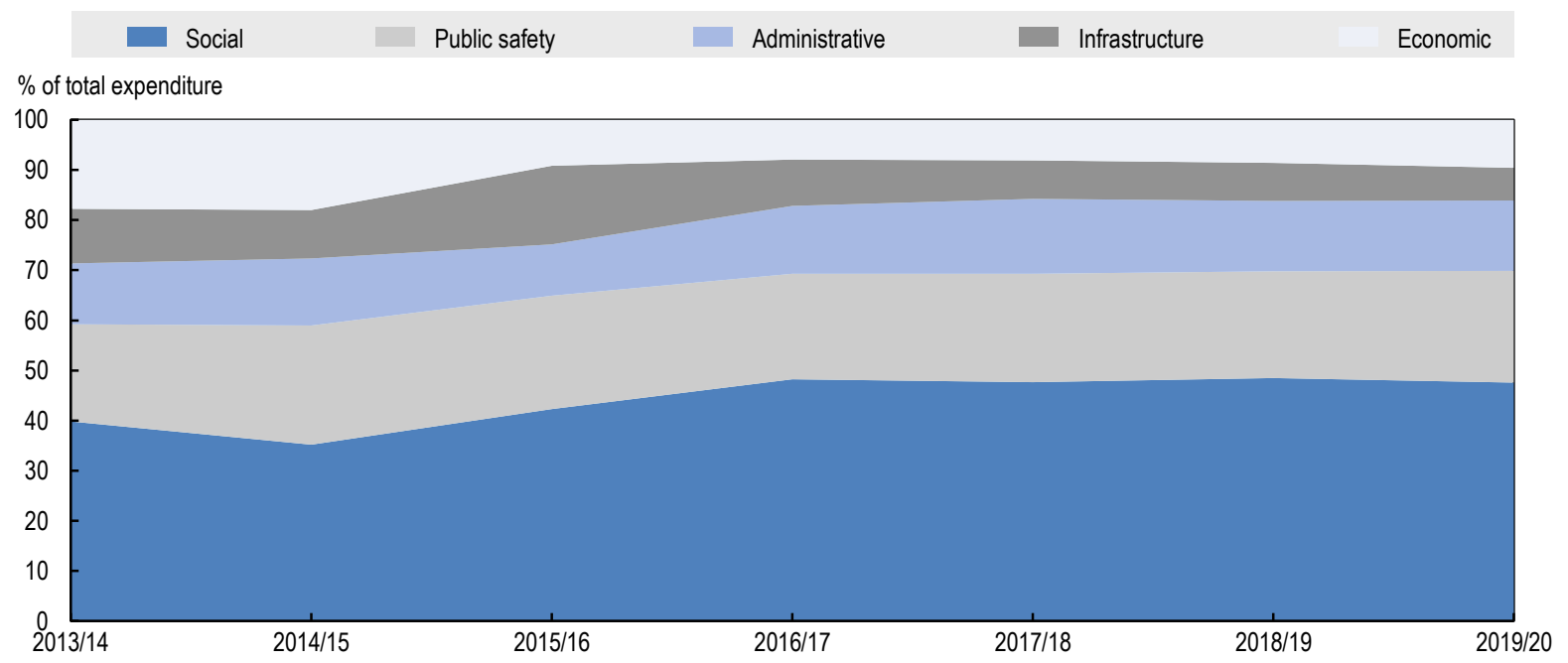

Note. Statutory expenditure has been excluded.

Source: Authors' calculation based on Ministry of Finance (various years), Medium-term Expenditure Framework, available at www.mof.gov.na. 
Budget allocations to the social sector have remained stable despite the GRN's efforts at fiscal consolidation. Figure 3.3, which aggregates government spending into five main categories, illustrates the GRN's commitment to funding its social sector. While around $20 \%$ of the budget is devoted to infrastructure and economic development, more than $40 \%$ is allocated to ministries dealing with social affairs, although a significant proportion of these resources consists of salaries for civil servants.

The public sector wage bill is the largest single area of public spending by economic classification. In 2017/18, 44.9\% of the total budget was spent on the salaries of government employees, an increase of 5.2\% from 2016/17. In comparison, the education category, comprised of Education, Arts and Culture and Higher Education, Training and Innovation, currently receives a combined share of $24.1 \%$; Health and Social Services, the next largest spending category, receives $10.4 \%$ of total expenditure. The Ministry of Defence receives the third highest allocation of $9.1 \%{ }^{4}$

\subsubsection{Government revenue}

Government revenue is expected to decrease over the medium term, reflecting a decline in transfers from SACU's Common Revenue Pool (Figure 3.4). According to the IMF, revenue as a percentage of GDP will decline from $35.4 \%$ in $2014 / 15$ to an estimated $34.2 \%$ in $2017 / 18$ and a projected $30.9 \%$ in $2020 / 21$ (IMF, 2018 $[21]$ ).

Figure 3.4. Namibia's revenues are declining as a percentage of GDP

Total government revenue and grants (2014/15-2020/21)

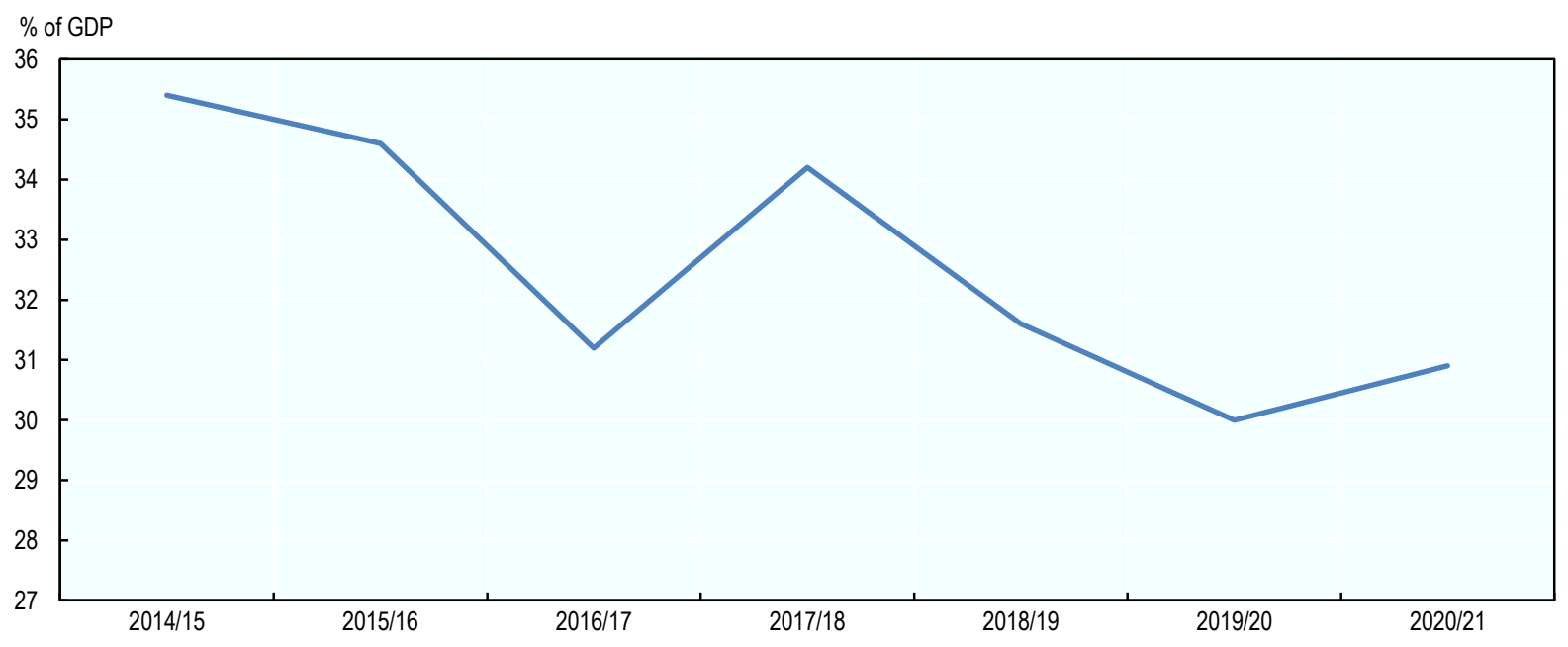

Source: IMF (2018[21]), Namibia: Article IV Consultation, International Monetary Fund, Washington DC.

Taxes on income and profits constitute the GRN's main source of tax revenue, contributing $38.8 \%$ to total revenue in 2016/17 (Figure 3.5). The share is expected to have declined to $33.9 \%$ in $2017 / 18$. Likewise, the share of value-added tax is expected to decline slightly, from $26.4 \%$ in $2016 / 17$ to $25.1 \%$ in $2017 / 18$. Although the tax system is slightly progressive overall, direct social protection transfers are the main determinant of the reductions in poverty and inequality achieved through the fiscal system (see Box 3.1). 
Box 3.1. Fiscal policy as a whole is key to reducing poverty and tackling inequalities

According to recent fiscal incidence analysis carried out by the World Bank, Namibia's social protection spending (principally the grants documented in Section 1) is highly effective at reducing poverty and inequality (Sulla et al., 2017 ${ }_{[22]}$ ). Namibia's overall fiscal system, including other forms of social spending and the tax revenues that finance this expenditure, reinforce the impact of direct transfers.

Based on administrative and household-level data for 2009/10, the analysis showed that social assistance grants, which are fully funded from the government budget, are well targeted and adequate. Overall, they reduced extreme poverty* by 6.8 percentage points in 2009/10, meaning that the extreme poverty headcount ratio without social assistance in that year would have been $22.2 \%$ instead of $15.4 \%$.

The progressive impact of direct transfers is supported by water subsidies for rural residents, while the combined impact of in-kind health and education services is approximately neutral. Poor households benefit more than wealthier households from primary education and outpatient healthcare, although the education system becomes less progressive at higher levels.

Crucially, Namibia's tax system is also progressive. A progressive personal income tax schedule means that lower-income earners are exempted from paying this tax, while combined indirect taxes (including the value-added tax) are neutral. As a result, the impact of social assistance and other social spending in reducing poverty and inequality are reinforced by the mechanisms for financing this expenditure. As a result, Namibia's fiscal system achieves a similar degree of redistribution as that of South Africa.

The results of a study by the Namibia Statistics Agency on child poverty indicate similar results on the effectiveness of social assistance (NSA, 2012[23]): the provision of social grants was shown to reduce child poverty by almost seven percentage points, from $40.8 \%$ to $34.0 \%$. Further strengthening the case for an expansion of the current grant system, a study based on a micro-simulation model for Namibia indicated that "child poverty could be reduced from $34 \%$ to $9 \%$ and extreme child poverty would be eliminated" if the current child grant system were made universal (UNICEF, 2017 [24]).

However, Sulla et al. find that Namibia should improve the targeting of social assistance to increase its reduction in poverty. They also warn that redistribution alone cannot accomplish poverty eradication and achieve an equal society. Fiscal policy needs to be supported by policies that create a conducive environment for job creation.

* Using the lower bound poverty line of NAD 277.54. 
Mining companies contributed 5.9\% of total revenue in 2017/18 through company taxes and mineral royalties (Figure 3.5). Diamond mining is the main contributor, accounting for $90.4 \%$ of this revenue. Once the Husab uranium mine reaches full production, royalties from other minerals are expected to more than double from an estimated NAD 199 million in 2017/18 to NAD 466 million in 2019/20.

Figure 3.5. Main sources of revenue have fluctuated over time

Contribution of main revenue sources to total revenue (1997/98-2019/20)

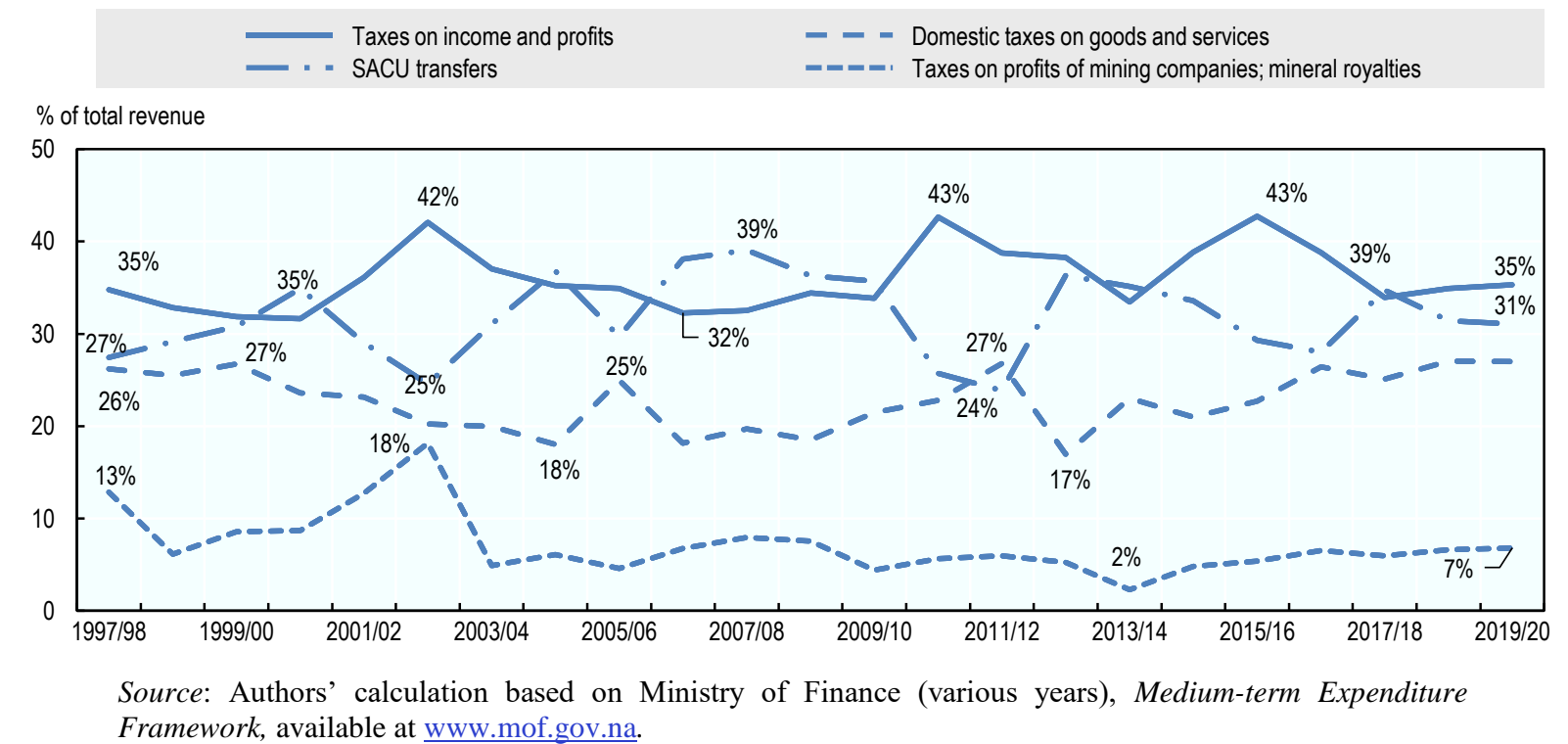

Foreign grants channelled through the State Revenue Fund and included in the national budget account for only $0.3 \%$ of total revenue. However, the actual amount of grants is higher, since funding for the health sector in particular, such as the US President's Emergency Plan for Aids Relief (PEPFAR) and Global Fund contributions, are not channelled through the State Revenue Fund and hence not recorded in budget documents. 



\section{Conclusion and recommendations}

Namibia has developed one of the most comprehensive social protection systems in Africa. This has been matched by a strong financial commitment. Since independence, the GRN has devoted a steadily-growing proportion of public spending to social protection. Spending on core social assistance programmes increased from 1.3\% of GDP in 2000/01 to 3.5\% of GDP in 2015/16. While $4.0 \%$ of the national budget was spent on these arrangements in 2000/01, the share rose to $8.3 \%$ in 2015/16.

Meanwhile, expenditure by public social insurance institutions has also increased, although these arrangements are mostly available only to workers in the public sector. Spending by social insurance programmes covering the public sector increased from $2.1 \%$ of GDP to $2.9 \%$ of GDP between 2001/02 and 2015/16. Expenditure by the Social Security Commission (SSC), which covers the public and private sectors, increased from $0.18 \%$ to $0.25 \%$ of GDP over the same period.

Expenditure by private contributory social protection arrangements (pension funds and medical aid schemes) has also grown strongly. Spending was equivalent to $6.3 \%$ of GDP in 2015, up from $4.3 \%$ in 2002. Private arrangements accounted for just under half of total social protection spending in 2015/16, which was equivalent to $13 \%$ of GDP.

Spending on social assistance has been shown to be highly effective at reducing poverty and inequality, although there are limits to what can be achieved in this regard through redistribution alone. Nonetheless, there exists a strong case for increasing spending on the grant system, especially since the mechanisms by which it is financed have also been shown to be progressive, meaning that they place a very small burden on the poor.

However, the prospects for higher allocations for social assistance are not benign due to low economic growth, a high fiscal deficit and rising debt levels. Meanwhile, the GRN has a range of competing priorities, notably infrastructure development, and the size of the public sector wage bill significantly reduces its spending flexibility.

In a context where real growth in tax-financed social protection spending will be difficult to achieve, it is necessary to maximise the efficiency of non-contributory arrangements. This means reprioritising allocations to the programmes most effective at reducing poverty, ensuring that targeting mechanisms (where these exist) operate efficiently and that synergies are achieved between programmes to reduce administrative costs.

Increasing coverage of social insurance programmes is another means of alleviating pressure on public finances, in particular where these substitute for the old age or disability grants. However, Namibia lacks both a public pension fund and a public medical aid scheme (otherwise known as a system of national or social health insurance). Although private arrangements operate at scale, there are important gaps in coverage, especially at low-income levels. Discussions are underway regarding the introduction of public pension and health arrangements but progress towards implementation appears slow. 
As a result, public social security arrangements are principally accessible only by public servants. Moreover, $86 \%$ of spending by the Public Service Employees Medical Aid Scheme (PSEMAS) is financed from general revenue rather than members' contributions. As such, it is serving to crowd out other items of public spending.

\subsection{Recommendations}

This final section makes specific recommendations on how to enhance the impact of social protection in a constrained fiscal environment.

\subsubsection{Consolidate social protection oversight}

Social assistance provision - including grants and social welfare - is highly fragmented. This generates costly inefficiencies, causes gaps or duplications in coverage, and makes it difficult for the population to understand their entitlements. Addressing this fragmentation through a more systematised approach to social protection would optimise the poverty-reducing impact of social assistance and free up resources to reach more beneficiaries, to improve benefits and services or both with the existing budget.

A systems approach to social assistance requires analysis of institutional arrangements, policy alignment, information systems and delivery mechanisms. A comprehensive examination of the social assistance system is beyond the scope of this paper. However, the following key issues have emerged from the previous sections.

At present, grant programmes fall under the responsibility of three institutions: the Ministry of Gender Equality and Child Welfare (MGECW), the Ministry of Poverty Eradication and Social Welfare (MPESW) and the Ministry of Veterans Affairs (MVA) within the Office of the Vice President. MGECW is responsible for the four child grants, MPESW is responsible for the disability and old-age grants and MVA for the veterans grant.

These different sets of grants have followed different trajectories. The universal grants managed by MPESW have increasing benefits in line with inflation to maintain their value in real terms, while the child grants have declined in real terms (although this has been partially offset by the school feeding programme, which is administered by the Ministry of Education, Arts and Culture). However, the child grants have expanded coverage at a much faster rate, reflecting the high levels of child poverty relative to the population as a whole.

In a context of fiscal constraints, these dynamics require careful management. Separating the institutions responsible for the provision of social assistance renders them (to a certain extent) competitors for funds; the Ministry of Finance and other budgetary institutions or bodies are ultimately responsible for allocating resources between them, even though they might lack technical expertise in social protection.

Two alternatives to this arrangement might be feasible. First, the merging of responsibility for grant payments under one Ministry; secondly, the establishment of a supra-ministerial body with responsibility for managing budgetary allocations to the sector. A risk of the first option is that it separates cash transfers for a particular group from the broader policy framework for that particular group. Addressing child poverty, for example, requires a multi-faceted response of which the different grants are components. Under the second option, different ministries retain control of the design of different grants but must co-ordinate better with each other. 


\subsubsection{Strengthen information and delivery systems}

The establishment of an institution with oversight for social assistance is not sufficient to optimise the allocation of resources. Another key requirement is the information base, starting with fundamental data on the population. Working with the Ministry of Home Affairs to better understand population dynamics and ensuring that individuals have the documents that they require to access benefits is critical, especially where undocumented individuals are most likely to be poor or vulnerable.

Namibia Statistics Agency also has a critical role to play. The National Household Income and Expenditure Survey, conducted every five years, is a resource for learning about poverty dynamics and gaining information about the effectiveness of different social protection programmes. This information can be used to understand which interventions are most effective in reducing poverty that should in turn be used to inform the allocations across social assistance.

Information from representative surveys should be complemented by detailed programme-level data that contains information about individual beneficiaries. Over time, this information would be centralised across all social assistance programmes to ensure that beneficiaries are accessing the correct benefits (thereby avoiding exclusion errors or duplication) and can be linked automatically to other interventions, such as complementary social services or labour-activation programmes.

Cost efficiencies can also be generated by optimising the delivery mechanisms for social assistance. There is a range of different delivery mechanisms for social grants, including cash, bank transfers and post offices. Each mechanism has its own constraints and cost structure. Worryingly, administrative costs for the old age and disability grants have increased significantly in recent years.

Increasing the proportion of grant beneficiaries who receive their benefit through bank transfers reduces administrative costs at the same time as enhancing financial inclusion. However, it will not be possible to move over entirely to such a system, given Namibia's size, low population density and infrastructure constraints, which imply that a certain proportion of beneficiaries might not be able to access banks.

Development partners can support the development of systems. Namibia's status as an upper-middle-income country means it is not eligible for concessional finance to increase the scope of its social protection system. At the same time, rising debt levels reduce the GRN's potential to borrow at market rates to do this. However, leveraging the global expertise of development partners in different types of social protection information or delivery system can significantly increase the efficiency of social protection spending.

\subsubsection{Consolidate rather than universalise}

It is possible to generate efficiencies in social assistance expenditure by reconsidering the design and configuration of different grants. Namibia implements a poverty-targeted approach to child grants but a universal approach to old age and disability transfers. Depending on the availability of resources, it might be desirable to reassess these approaches or the parameters on which they are based.

The child grant system is relatively complex. Four grants cover different groups but pay the same benefit levels. The maintenance and vulnerable child grants also impose a means test at a very low level to determine eligibility. This threatens to exclude a large part of the working poor (thereby risking perverse incentives with regard to labour force 
participation, false reporting or resentment and stigmatisation between grant beneficiaries and the working poor). The income-related requirement also makes it harder for potential beneficiaries to understand and apply for benefits, and it increases the cost of administering the programmes.

Creating a universal child grant would reduce many of the administrative costs associated with the child grants at the same time as eliminating exclusion errors (except where eligible individuals are excluded due to lack of documentation). However, the cost of such a measure would be prohibitive. Indeed, in the current context, even expanding coverage of the child grants in order to address child poverty risks driving down benefit values further in real terms. Nonetheless, it is worth exploring consolidation and simplification of the child grants.

The old age and disability grants have proven notably resistant to cyclical trends in the economy. As such, they demonstrate the sustainability of a universal approach to social protection, as well as their importance in a context of large gaps in social insurance coverage, especially at lower income levels and among informal workers.

\subsubsection{Strengthen resilience to climate shocks}

The prevalence of poverty in Namibia is strongly influenced by geography and climate, often both. At present, Namibia's response to a climate-related emergency is largely reactive. As noted above, drought relief is paid when droughts strike, leading to sudden spikes in spending such as in 2016/17. However, such increases in spending are not always easy to accommodate in a fiscally constrained context.

Namibia's policy for disaster risk management, published in 2009, states that "A key element of disaster-risk management is to make livelihoods disaster-resilient... This means a move away from emergency relief towards budgeted national safety nets that deliver timely, adequate, predictable and guaranteed transfers" (Republic of Namibia, $\left.2009_{[25]}\right)$. A decade later, this requirement remains unfulfilled.

There is growing international evidence that putting social protection at the centre of ex ante responses to climate shocks makes sense from a financial as well as a livelihoods perspective. Where households use cash transfers and other social protection mechanisms to diversify crops to mitigate the threat of a climate shock, their yields (and incomes) are likely to increase. From the perspective of public finances, a more resilient population reduces the cost of emergency assistance, and regular transfers are easier to budget for.

This is another area where information systems can play a key role and generate savings in the long term. Identifying households in at-risk areas before a climate crisis occurs makes it possible to make immediate transfers to vulnerable groups. Creating a link between this database and climate early warning systems is critically important.

\subsubsection{Address inequalities and imbalances in social insurance schemes for public servants}

Periods of economic decline or stagnation might not be propitious for the introduction of social insurance systems, for a number of potential reasons. For example, the macroeconomic priority might be for stimulating demand rather than enforcing savings through mandatory contributions. Social security contributions also represent a tax on labour, increasing the cost of employment and dampening employment creation, weakening economic prospects at an individual and an aggregate level. 
As a consequence, the opportunities for higher coverage of social insurance mechanisms to alleviate pressure on tax-financed social protection are limited. Ongoing discussions on a new public pension arrangement and a system of social health insurance (populationwide medical aid) are likely to be contentious and slow-moving at any point in the business cycle but will find the going especially tough at present.

Nonetheless, it is imperative that arrangements for public-sector workers do not impose a further strain on public finances or weaken the social protection system. The fact that civil servants' contributions to PSEMAS are heavily subsidised by general revenue means they crowd out other social protection spending and undermines the equity of the social protection system. Moreover, the flat rate contributions for PSEMAS are regressive within the public sector. Restructuring and raising contribution rates is imperative from a fairness and a financial perspective.

Over the longer term, the solvency of the Government Institutions Pension Fund (GIPF) is a concern. Although the actuarial report for 2015 calculated the GIPF to be fully funded (with assets equivalent to $108 \%$ of liabilities), the report also found the strength of its financial position to be highly sensitive to assumptions regarding investment returns (GIPF, 2015[26]). This makes the GIPF vulnerable to the current slowdown, both in Namibia and neighbouring South Africa, whose capital markets better able to accommodate the size of the GIPF.

If the return on the GIPF's investments were to average $11 \%$ rather than $12 \%$ in the future, the funding level would be below the required $100 \%$ and the government's contribution will have to increase to fill the shortfall. It is also notable that the current contribution rate to the GIPF ( $7 \%$ by the employer and $16 \%$ by the employee) is significantly lower than is required to keep the GIPF fully funded over the long term.

Restoring the GIPF's funding levels by increasing the contribution rate would in turn increase the public sector wage bill at a time when the GRN is seeking to reduce it. Meanwhile, attempts to dramatically reduce the public sector headcount might also jeopardise the solvency of the fund if it generates an unanticipated reduction in the number of current GIPF members (whose contributions partly finance the benefits paid to those who leave the GIPF). As such, the GIPF could act as a brake on efforts to create fiscal space for social protection by reducing the wage bill.

In a context where it will be difficult to increase contribution rates or investment returns, two options exist: increasing the retirement age (currently set at 60, in line with the labour market as a whole) or reducing benefits by lowering the accrual rate for members (currently set at $2.4 \%$ of final salary for every year of service). Neither option is politically palatable.

\subsubsection{Develop a financing strategy for social protection}

The GRN is developing a social protection policy that will provide the framework for social protection in the future. This should be complemented by a financing strategy to ensure that proposals are affordable in the short term, sustainable over the long term and reflect the likely evolution of social protection needs. This strategy should be based on a range of different macroeconomic scenarios, not just the current, low-growth context.

A financing strategy typically maps spending on social protection by programme and by source of revenue (such as taxes or contributions). It tracks the evolution of spending on different programmes, assesses their value for money and overlays these programmes against economic and demographic projections to anticipate future demand. It also brings 
together the financing and impact of different programmes through fiscal incidence analysis, which demonstrates which groups benefit from social protection expenditure and which bear the burden of financing it.

Financial analysis should not focus solely on tax-financed programmes. In financial terms, the most significant reforms to social protection in Namibia might occur in social insurance, both in pensions and health insurance. Moreover, arrangements for public sector workers represent a long-term risks for public finances. It is relatively easy to delay measures to address imbalances in contributory arrangements, since the consequences might only be felt in the distant future. However, the longer that imbalances persist, the more painful the required adjustments will be.

\section{Notes}

1 The Namibia Labour Force Survey defines informal employment based on provision or availability of some form of formal social protection. Employment is considered informal if the employer does not cover the worker with at least a pension scheme, medical aid and /or social security.

2 Pensioners, war veterans and other vulnerable groups often receive additional benefits in the form of reduced fees or tariffs for television licenses and electricity, for example. These are not covered in this analysis.

3 A functioning civil registration system is a pre-requisite for an effective social protection scheme, since without civil registration and the necessary documents, such as birth certificates, it is not possible to access basic social services or grants. We have, however, excluded allocations to civil registration that falls under the Ministry of Home Affairs and Immigration from the following analysis.

${ }^{1}$ Namibia is a member state of the CMA along with Eswatini, Lesotho and South Africa.

2 Likewise, the exchange rate of the Namibian dollar is not a reflection of the economic performance of Namibia, but of events taking place in South Africa.

${ }^{3}$ Communal areas refer to the land that is owned by the state as opposed to commercial areas with free-hold land titles.

${ }^{4}$ This amount is less than in previous years, i.e. $11.0 \%$ for $2014 / 15$. 


\section{References}

Adema, W. and P. Fron (2019), The OECD SOCX Manual - 2019 Edition, OECD, Paris, http://www.oecd.org/social/soc/SOCX_Manuel_2019.pdf (accessed on 4 March 2019).

Dempers, U. (2016), Social Protection in Namibia: A Civil Society Perspective, Friedrich-EbertStiftung (FES), Namibia Office, https://cms.my.na/assets/documents/p1b2aoh5r914v4uktsusbucj1j4.pdf (accessed on 19 July 2018).

Education, M. (2012), The Namibian School Feeding Programme Transition Case Study, Ministry of Education, Republic of Namibia, https://documents.wfp.org/stellent/groups/public/documents/communications/wfp288990.pdf (accessed on 13 August 2018).

GIPF (2015), Report on the statutory actuarial valuation of the Government Institutions Pension Fund as at 31 March 2015, Government Institutions Pension Fund (GIPF), Windhoek, https://www.gipf.com.na/web/reports/actuarial/actuarial_report_2015.pdf (accessed on 7 February 2019).

IMF (2018), Namibia: 2017 Article IV Consultation - Press Release; Staff Report; and Statement by the Executive Director for Namibia, International Monetary Fund, Washington DC, https://www.imf.org/en/Publications/CR/Issues/2018/02/28/Namibia-2017-Article-IVConsultation-Press-Release-Staff-Report-and-Statement-by-the-45665 (accessed on 5 February 2019).

IMF (2018), World Economic Outlook (April 2018), International Monetary Fund, Washington, DC, http://www.imf.org/external/datamapper/PCPIEPCH@WEO/NAM (accessed on 16 August 2018).

Levine, S., S. van der Berg and D. Yu (2011), "The impact of cash transfers on household welfare in Namibia", Development Southern Africa, Vol. 28/1, pp. 39-59, http://dx.doi.org/10.1080/0376835X.2011.545169.

Menges, W. (2017), "United Africa loses state grants tender case - The Namibian", The Namibian, https://www.namibian.com.na/169617/archive-read/United-Africa-loses-stategrants-tender-case (accessed on 20 August 2018).

Ministry of Finance (2017), Estimates of revenue, income and expenditure 2017-2020, Ministry of Finance, Republic of Namibia, http://www.mof.gov.na/documents/27827/345303/Estimates+of+Revenue+Income+and+Expe nditure+2017-2018.pdf/558e6e95-bc5d-43f2-ad1a-3a393170803f (accessed on 7 February 2019).

Ministry of Gender Equality and Child Welfare (2010), The Effectiveness of Child Welfare Grants in Namibia, Ministry of Gender Equality and Child Welfare, https://www.unicef.org/namibia/MGECW_2010_Child_Grants_Report_Vol_1_summary.pdf (accessed on 4 March 2019). 
Ministry of Poverty Eradication and Social Welfare (2016), Blue print on wealth redistribution and poverty eradication, Government of Namibia, Windhoek, https://info.undp.org/docs/pdc/Documents/NAM/Blue\%20Print\%20on\%20Wealth\%20Redistr ibution\%20and\%20Poverty\%20Eradication\%20\%20PDF.pdf (accessed on 20 August 2018).

Namibia Statistics Agency (2017), Namibia Household Income and Expenditure Survey (NHIES) 2015-2016: Key Poverty Indicators (Preliminary Figures), Namibia Statistics Agency, Windhoek, http://www.nsa.org.na (accessed on 19 July 2018).

Namibia Statistics Agency (2017), The Namibia Labour Force Survey2016 Report, Namibia Statistics Agency, Windhoek, http://www.nsa.org.na (accessed on 19 July 2018).

National Housing Enterprise (n.d.), National Housing Enterprise, 2019, http://www.nhe.com.na/mass-housing/index.htm.

National Planning Commission (2017), Namibia's 5th National Development Plan, Republic of Namibia, https://www.npc.gov.na/?wpfb dl=294 (accessed on 28 February 2019).

NSA (2016), Namibia Labour Force Survey 2016, Namibia Statistics Agency, Windhoek, https://nsa.org.na/microdata1/index.php/catalog/25 (accessed on 16 August 2018).

NSA (2012), Child poverty in Namibia: a child-centered analysis of the NHIES, 2009/10., Namibia Statistics Agency (NSA), Windhoek, https://searchworks.stanford.edu/view/10500029 (accessed on 20 August 2018).

Republic of Namibia (2016), Blueprint for Wealth Redistribution and Poverty Eradication, Ministry of Poverty Eradication and Social Welfare, https://info.undp.org/docs/pdc/Documents/NAM/Blue\%20Print\%20on\%20Wealth\%20Redistr ibution\%20and\%20Poverty\%20Eradication\%20\%20PDF.pdf (accessed on 28 February 2019).

Republic of Namibia (2009), Disaster Risk Management (DRM) Policy, Republic of Namibia, Windhoek, https://www.preventionweb.net/english/professional/policies/v.php?id=21652 (accessed on 5 February 2019).

Schade, K. (2000), "Poverty", in Melber, H. (ed.), Namibia: a decade of independence 19902000, Namibian Economic Policy Research Unit, Windhoek, http://www.worldcat.org/title/namibia-a-decade-of-independence-1990-2000/oclc/248010695 (accessed on 20 August 2018).

Southern African Customs Union (2019), History of SACU, http://www.sacu.int/show.php?id=394 (accessed on 4 March 2019).

Sulla, V. et al. (2017), Does fiscal policy benefit the poor and reduce inequality in Namibia?, World Bank, Washington, DC, http://documents.worldbank.org/curated/en/991551497258273367/Does-fiscal-policy-benefitthe-poor-and-reduce-inequality-in-Namibia (accessed on 20 August 2018).

Tesliuc, C. et al. (2013), Botswana social protection assessment, World Bank, Washington, DC, http://documents.worldbank.org/curated/en/421451468199469145/Botswana-socialprotection-assessment (accessed on 20 August 2018). 
UNDP (2018), Human Development Indices and Indicators: 2018 Statistical Update Briefing on Namibia, United Nations Development Programme, New York, http://hdr.undp.org/en/data (accessed on 5 February 2019).

UNICEF (2017), Children and the Namibian Budget: Social assistance and welfare (2017/18 Budget), United Nations Children's Fund Namibia, Windhoek, https://www.unicef.org/esaro/UNICEF_Namibia_--_2017_-_Social_Assistance_and_Welfare_Budget_Brief.pdf.

Westphal, T. (2015), "South Africa: Extending social protection to children", Building Social Protection Floors Country Note Series, ILO Social Protection Department, International Labour Office, International Labour Organization, http://www.socialprotection.org/gimi/RessourcePDF.action?ressource.ressourceId=53472 (accessed on 19 July 2018).

World Bank (2012), Affordability and financing of social protection systems, World Bank, Washington, DC,

http://documents.worldbank.org/curated/en/946111468002405150/Affordability-andfinancing-of-social-protection-systems (accessed on 29 June 2018). 


\section{Annex A. Classification of social protection programmes}

Table A.1. Non-contributory social protection programmes

\begin{tabular}{|c|c|c|}
\hline Institution & Core & Broad (Labour market activation) \\
\hline \multirow[t]{5}{*}{ Ministry of Gender Equality and Child Welfare } & Foster Care Grant & Income Generating Activities \\
\hline & Maintenance Grant & Early Childhood Development - Subsidy for educarers \\
\hline & Special Maintenance Grant & \\
\hline & Vulnerable Child Grant & \\
\hline & Allowance for war orphans & \\
\hline $\begin{array}{r}\text { Ministry of Gender Equality and Child Welfare } \\
\text { main division } 06\end{array}$ & Place of safety & \\
\hline \multirow{2}{*}{$\begin{array}{r}\text { Ministry of Gender Equality and Child Welfare } \\
\text { main division } 05 \text {-Child Care Facilities and } \\
\text { protection }\end{array}$} & Shelter & \\
\hline & RCCF subsidy & \\
\hline \multirow{4}{*}{$\begin{array}{r}\text { Ministry of Poverty Eradication and Social } \\
\text { Welfare }\end{array}$} & Old Age Grant & \\
\hline & Disability Grant & \\
\hline & Funeral benefit & \\
\hline & Food bank & Street committee allowance \\
\hline \multirow[t]{6}{*}{ Ministry of Veteran Affairs } & Veterans' subvention grant & Veterans Education \& Training Grant \\
\hline & Veterans once-off gratuity & Mental health counselling for War Veterans \\
\hline & Veterans projects & \\
\hline & Veterans Funeral assistance & \\
\hline & War Veterans Houses & \\
\hline & War Veterans Farms & \\
\hline Ministry of Education, Arts and Culture & School feeding programme & \\
\hline Ministry of Health and Social Services & Dev Social Welfare & \\
\hline Ministry of Urban \& Rural Development & Social housing projects & Youth Employment Scheme \\
\hline Office of the Prime Minister & Drought Relief & \\
\hline \multirow[t]{5}{*}{ Social Security Commission } & Occupational injuries & \\
\hline & Employees Compensation Fund & \\
\hline & Sick leave benefit & \\
\hline & Maternity leave benefit & \\
\hline & Death benefit & \\
\hline Ministry of Finance / PSEMAS & $\begin{array}{r}\text { Public service employee medical aid } \\
\text { scheme }\end{array}$ & \\
\hline Government Institution Pension Fund & Public pension fund & \\
\hline Private medical aid schemes & Private medical aid & \\
\hline Private pension funds & Private pension funds & \\
\hline $\begin{array}{r}\text { Ministry of Higher Education, Training and } \\
\text { Innovation }\end{array}$ & & Vocational training \\
\hline Namibia Students Financial Assistance Fund & & Bursary tertiary education \\
\hline
\end{tabular}


Table A.2. Core contributory social protection programmes

\begin{tabular}{rrr}
\hline Scheme & Public & Private \\
\hline Pension funds & Government Institutions Pension Fund & Various private sector pension funds \\
Medical aid funds & Public sector employee medical aid & Various private sector medical aid \\
funds \\
scheme
\end{tabular}




\section{Annex B. Public expenditure on social protection in Namibia (2000-17)}

Table B.1. Total expenditure on non-contributory programmes, in NAD million

\begin{tabular}{|c|c|c|c|c|c|c|c|c|c|c|}
\hline & $2000 / 01$ & $2004 / 05$ & $2009 / 10$ & $2010 / 11$ & $2011 / 12$ & $2012 / 13$ & $2013 / 14$ & $2014 / 15$ & $2015 / 16$ & $2016 / 17$ \\
\hline Broad & 14.56 & 68.81 & 329.84 & 347.74 & 557.22 & 946.24 & 993.20 & 1390.31 & 2030.27 & 1814.72 \\
\hline \multirow[t]{2}{*}{ Core } & 345.59 & 600.82 & 1603.22 & 1833.53 & 2854.07 & 2791.69 & 2754.11 & 4145.18 & 5118.56 & 5501.26 \\
\hline & & $2002 / 03$ & $2006 / 07$ & $2009 / 10$ & $2010 / 11$ & $2011 / 12$ & $2012 / 13$ & $2013 / 14$ & $2014 / 15$ & $2015 / 16$ \\
\hline Public* & & 1358.46 & 2268.06 & 3679.81 & 3988.72 & 5438.86 & 5465.19 & 6012.50 & 7705.00 & 9458.56 \\
\hline Private** & & 1483.79 & 2656.56 & 3861.40 & 4335.22 & 4239.41 & 4913.33 & 5824.89 & 7179.36 & 9245.98 \\
\hline \multirow[t]{2}{*}{ SSC } & & 61.85 & 66.24 & 149.06 & 161.20 & 198.36 & 238.79 & 285.88 & 299.58 & 366.98 \\
\hline & & $2002 / 03$ & $2006 / 07$ & $2009 / 10$ & $2010 / 11$ & $2011 / 12$ & $2012 / 13$ & $2013 / 14$ & $2014 / 15$ & $2015 / 16$ \\
\hline Contributory $^{\star * *}$ & & 2373 & 4083 & 6087 & 6652 & 7023 & 7826 & 9369 & 11039 & 13953 \\
\hline Non-contributory & & 531 & 908 & 1603 & 1834 & 2854 & 2792 & 2754 & 4145 & 5119 \\
\hline
\end{tabular}

Note: * Non-contributory and contributory.

** Contributory.

*** Public, private SSC.

Source: Ministry of Finance, Estimates of Revenue and Expenditure, Namfisa, SSC, GIPF.

Table B.2. Social protection expenditure, as \% of GDP

\begin{tabular}{lrrrrrrrrrr}
\hline & $\mathbf{2 0 0 2 / 0 3}$ & $\mathbf{2 0 0 5 / 0 6}$ & $\mathbf{2 0 0 9 / 1 0}$ & $\mathbf{2 0 1 0 / 1 1}$ & $\mathbf{2 0 1 1 / 1 2}$ & $\mathbf{2 0 1 2 / 1 3}$ & $\mathbf{2 0 1 3 / 1 4}$ & $\mathbf{2 0 1 4 / 1 5}$ & $\mathbf{2 0 1 5 / 1 6}$ \\
\hline $\begin{array}{l}\text { Total public expenditure on social } \\
\text { protection }\end{array}$ & 8.4 & 7.0 & 10.2 & 10.3 & 11.0 & 9.9 & 9.9 & 10.9 & 12.9 \\
& $\mathbf{2 0 0 0 / 0 1}$ & $\mathbf{2 0 0 4 / 0 5}$ & $\mathbf{2 0 0 9 / 1 0}$ & $\mathbf{2 0 1 0 / 1 1}$ & $\mathbf{2 0 1 1 / 1 2}$ & $\mathbf{2 0 1 2 / 1 3}$ & $\mathbf{2 0 1 3 / 1 4}$ & $\mathbf{2 0 1 4 / 1 5}$ & $\mathbf{2 0 1 5 / 1 6}$ & $\mathbf{2 0 1 6 / 1 7}$ \\
\hline Core (non-contributory) & 1.3 & 1.4 & 2.1 & 2.2 & 3.2 & 2.6 & 2.2 & 3.0 & 3.5 & 3.4 \\
Broad (non-contributory) & 0.1 & 0.2 & 0.4 & 0.4 & 0.6 & 0.9 & 0.8 & 1.0 & 1.4 & 1.1 \\
& & $\mathbf{2 0 0 2 / 0 3}$ & $\mathbf{2 0 0 6 / 0 7}$ & $\mathbf{2 0 0 9 / 1 0}$ & $\mathbf{2 0 1 0 / 1 1}$ & $\mathbf{2 0 1 1 / 1 2}$ & $\mathbf{2 0 1 2 / 1 3}$ & $\mathbf{2 0 1 3 / 1 4}$ & $\mathbf{2 0 1 4 / 1 5}$ & $\mathbf{2 0 1 5 / 1 6}$ \\
\hline Contributory public SP expenditure & & 2.4 & 2.6 & 2.8 & 2.6 & 2.9 & 2.5 & 2.7 & 2.6 & 2.9 \\
Private SP expenditure & 4.3 & 5.0 & 5.1 & 5.2 & 4.7 & 4.6 & 4.7 & 5.2 & 6.3 \\
SSC & 0.18 & 0.12 & 0.20 & 0.20 & 0.22 & 0.22 & 0.23 & 0.22 & 0.25 \\
\hline
\end{tabular}

Source: Ministry of Finance, Estimates of Revenue and Expenditure, Namfisa, SSC, GIPF.

Table B.3. Social protection expenditure, as \% of total public expenditure

\begin{tabular}{|c|c|c|c|c|c|c|c|c|c|c|}
\hline & $2000 / 01$ & $2004 / 05$ & $2009 / 10$ & 2010/11 & $2011 / 12$ & $2012 / 13$ & $2013 / 14$ & $2014 / 15$ & $2015 / 16$ & $2016 / 17$ \\
\hline Core: non-contributory SP & 4.0 & 4.7 & 6.4 & 6.7 & 7.8 & 7.3 & 5.9 & 7.0 & 8.3 & 8.9 \\
\hline Broad: non-contributory SP & 0.2 & 0.5 & 1.3 & 1.3 & 1.5 & 2.5 & 2.1 & 2.4 & 3.3 & 3.0 \\
\hline
\end{tabular}

Source: Ministry of Finance, Estimates of Revenue and Expenditure, Namfisa, SSC, GIPF. 
Table B.4. Core non-contributory and contributor social protection expenditure, per capita, in NAD

\begin{tabular}{lrrrrrrrrr}
\hline & $2002 / 03$ & $2006 / 07$ & $2009 / 10$ & $2010 / 11$ & $2011 / 12$ & $2012 / 13$ & $2013 / 14$ & $2014 / 15$ & $2015 / 16$ \\
\hline $\begin{array}{l}\text { Core public non-contributory SP } \\
\text { expenditure per capita }\end{array}$ & 282.39 & 456.37 & 772.90 & 867.71 & 1325.49 & 1272.34 & 1231.81 & 1819.41 & 2204.76 \\
\begin{tabular}{l} 
Contributory SP expenditure per capita \\
\hline
\end{tabular} & 1260.75 & 2052.16 & 2934.51 & 3147.83 & 3261.41 & 3566.61 & 4190.47 & 4845.16 & 6010.08 \\
\hline
\end{tabular}

Source: Ministry of Finance, Estimates of Revenue and Expenditure, Namfisa, SSC, GIPF. 